\title{
Convalescent Plasma Therapy for Management of COVID-19: Perspectives and Deployment in the Current Global Pandemic
}

This article was published in the following Dove Press journal: Risk Management and Healthcare Policy

\author{
Nandeeta Samad (iD) \\ Temitayo Eniola Sodunke (D) ${ }^{2}$ \\ Hasan Al Banna (D) ${ }^{3}$ \\ Ashmita Sapkota (iD ${ }^{4}$ \\ Aneeka Nawar Fatema $\mathbb{I D}^{5}$ \\ Katia Iskandar $\mathbb{D D}^{6}$ \\ Dilshad Jahan (iD) \\ Timothy Craig Hardcastle $\mathbb{1 D}^{8}$ \\ Tanzina Nusrat (iD) \\ Tajkera Sultana Chowdhury ${ }^{10}$ \\ Mainul Haque (D) ${ }^{11}$ \\ 'Department of Public Health, North \\ South University, Dhaka 1229, Bangladesh; \\ ${ }^{2}$ University of Ilorin, llorin, Kwara State, \\ Nigeria; ${ }^{3}$ Institute of Social Welfare and \\ Research, University of Dhaka, Dhaka \\ 1000, Bangladesh; ${ }^{4}$ Department of \\ Microbiology, Mahidol University, \\ Ratchathewi, Bangkok 10400, Thailand; \\ ${ }^{5}$ Department of Microbiology, Prima Asia \\ University, Dhaka I213, Bangladesh; \\ ${ }^{6}$ School of Pharmacy, Lebanese University, \\ Beirut, Lebanon; ${ }^{7}$ Department of \\ Hematology, Asgar Ali Hospital, Dhaka \\ 1204, Bangladesh; ${ }^{8}$ Department of Surgery, \\ Nelson R Mandela School of Clinical \\ Medicine, University of KwaZulu-Natal, \\ Umbilo, Berea 400I, South Africa; \\ ${ }^{9}$ Department of Microbiology, Chittagong \\ Medical College, Chattogram 4203, \\ Bangladesh; ${ }^{10}$ Department of Urology, \\ Shaheed Suhrawardy Medical College \\ Hospital, Dhaka I207, Bangladesh; " Unit of \\ Pharmacology, Faculty of Medicine and \\ Defence Health, Universiti Pertahanan \\ Nasional Malaysia (National Defence \\ University of Malaysia), Kuala Lumpur \\ 57000, Malaysia
}

Correspondence: Mainul Haque Unit of Pharmacology, Faculty of Medicine and Defence Health, Universiti Pertahanan Nasional Malaysia (National Defence University of Malaysia), Kem Perdana Sungai

Besi, Kuala Lumpur 57000, Malaysia

Tel +60109265543

Email runurono@gmail.com

\begin{abstract}
The world is striving against the severe crisis of the COVID-19 pandemic. Healthcare professionals are struggling to treat their patients based on nonspecific therapies. Amidst this uncertainty, convalescent plasma therapy (CPT) has appeared to be an interim adjuvant therapy for severely ill patients of COVID-19 until long-term clinical trial treatment options are available. Considering the transfusion-related hazards, especially lung injuries and microbial transmission, where sensitivity is not ensured, rigorous trials should be conducted to determine this therapy's efficacy. Moreover, the ratio of recovered cases to plasma donors is not satisfying, which questioning this therapy's availability and accessibility. Although some countries are making the treatment free, the attributable cost mandates a justification for its suitability and sustainability. Our article aimed to review the published facts and findings of CPT's effectiveness in lowering the mortality rate of COVID-19. This pandemic showed that healthcare systems worldwide need core reform. A unified global collaboration must align and coordinate to face the current pandemic and enhance world readiness for future outbreaks based on health equity and equality.
\end{abstract}

Keywords: convalescent plasma therapy, safety, risk, availability, accessibility, COVID-19, global pandemic

\section{Introduction}

According to WHO's situation report (October 16, 2020), the total confirmed cases of COVID-19 are 38,789,204, with a total death estimate of 1,095,097 globally. ${ }^{1}$ The number of affected persons and deaths are increasing in two hundred sixteen countries. ${ }^{1}$ About 5.48 million people have already recovered from this virus globally. ${ }^{1}$ Although precautionary measures have been notable for preventing transmission, including maintaining social distancing, personal hygiene, and faceprotection with masks, there is currently no approved vaccine for curing this virus. Scientists have been extensively looking into cures for this disease. They have suggested medicines including Hydroxychloroquine, Favipiravir, Remdesivir, dexamethasone, and a few others that have been used by healthcare professionals for the antiviral effect against the COVID-19.,3 Some of these treatments have proved useful in the healing process of COVID-19, but these medications' long-term clinical benefits are not yet well established. Nevertheless, convalescent plasma therapy (CPT) has recently become the focus of attention as it has earlier evidence supporting this CPT as a treatment option among COVID-19 patients. ${ }^{4,5}$ 
Taking into account the limited data available for the treatment of COVID-19, long-established and traditional interventions have re-emerged as viable options in the regulation of this disease. ${ }^{4}$ This is typical in the case of $\mathrm{CPT}$, a technique that entails passive immunization, which has been adopted in the management and prevention of diseases since the early 20 th century. ${ }^{5}$ The production of CPT consists of apheresis plasma from survivors with previous infections caused by the same infective microbes who have developed antibodies against the causative agent. The focus here is to enhance resistance against the pathogen by neutralization of the offending antigen. ${ }^{6} \mathrm{CPT}$ has indications as an emergency intervention in several pandemics: West Nile virus, Spanish flu, SARS-CoV, and, in recent times, the Ebola virus, based on its availability, accessibility, and cost-effectiveness. ${ }^{7-11}$ Instances of severe acute respiratory infections of viral origin, such as influenza, resulted in a decline in mortality rate after early CPT administration compared with placebo or untreated cases. $^{7,12}$

One study suggested that CPT plays a critical role, especially in low-and-middle-income countries (LMICs), as this therapy minimizes ventilator-need. Additionally, access to ventilators are extremely costly, therefore, either the patient cannot afford them, or availability is limited. ${ }^{13}$ It appears that CPT works effectively at the primary stage of being infected with the virus. ${ }^{14}$ Bangladesh being an LMIC, has also adopted the CPT strategy since the country's population affected by the COVID-19 is increasing day by day. A total of confirmed cases, recovered, and deceased were 249,651, 143,824 [57.6\% (Recovery Rate)], and 3306 [1.3\% (Fatality Rate)], respectively till August 7, 2020. ${ }^{15}$ The recovered patients remain instrumental donors in the recovery process for the currently infected patients. ${ }^{16,17}$ Overall, this trend has now necessitated the need to investigate CPT's reliability as a cure for COVID-19 victims.

\section{The Rationale of Convalescent Plasma as a Treatment Option}

To manage infection of certain diseases, the patient may be prescribed antibodies against the specific antigen. ${ }^{18-21}$ The immune system and antibodies respond to any infectious ailments either due to infective pathogenic microbes or due to the response towards a specific vaccine against particular infective disorders. ${ }^{22}$ The production of antibodies requires time, and the time necessary for the immune system depends on individual patients or the recipient immune system. ${ }^{23-26}$ Therefore, antibodies recovered from similar patients or artificially generated in animals are considered one way to offer instant immunity among susceptible cases for a brief period. ${ }^{27-29}$ This therapeutic concept has a long-standing history. It was practiced as far back as the late nineteenth century (the 1890s) as whole blood or plasma administration among patients vulnerable to microbial infectious diseases. ${ }^{5,24,30-34}$ The German physiologist, the first Nobel laureate in Medicine and the father of serum therapy, Emil Adolf von Behring (18541917), won the prestigious Prize in 1901 for his discovery of serum therapy for the treatment of diphtheria. ${ }^{35,36}$ Additionally, Emil Adolph von Behring and a Japanese physician and bacteriologist Shibasaburo Kitasato (18521931) revealed tetanus immunity's treatment strategy utilizing rabbit serum. ${ }^{37,38}$

The fundamental physio-pharmacological concept comprising passive immunization have added efficacy when used prophylactically than for the curative purpose of the infectious disease. Moreover, if the antibodies are administered as curative therapy, these need to be given as early as possible when the symptoms and signs develop of the particular infectious disease to maximize efficacy and to obtain the desired treatment outcome. ${ }^{18}$ This timing has not been clearly determined. It may be possible that the amount of antigens are much higher than the antibodies when the disease process turns to a full-blown severe disease reducing the effect. ${ }^{39-41}$ Another study revealed that antibodies work through inhibiting inflammatory processes, and this inhibitory effect is principally achieved when the infectious disease process is at the beginning stage, or the patient still asymptomatic. ${ }^{42,43}$

\section{Objectives of the Review}

The aim and scope of this review is to highlight the role of CPT as a therapeutic option in the management of the current global pandemic COVID-19 pandemic.

\section{Materials and Methods}

The literature search for this narrative review was performed by searching two core scientific literature databases (Google Scholar and PubMed). The authors relied on open access journals and access to journals granted by the Universiti Pertahanan Nasional Malaysia [(UPNM), the National Defence University of Malaysia], Kuala Lumpur, Malaysia, since the current work was unfunded. Articles for which full text was not available and those not 
written in English were excluded. The only non-English papers utilized refer to the history of CPT. The study was conducted between July-22-2020 to September-10-2020. The search terms used were: "Convalescent Plasma Therapy", "Convalescent Plasma", "CPT", "CP", "Plasma Therapy", "Viewpoints", "Arrangement", "Management", “Treatment", “Therapeutic Options", “Treatment Choices", "Existing”, "Present", "Prevailing”, "Worldwide", "International", "COVID-19" followed by snowballing references cited by critical articles. We had included all types of peer-reviewed articles published in English. Subsequently, after the search's first round, additional references were recognized by a labor-intensive search in the selected references. The present article's narrative nature, recent papers, and older papers with historical significance were incorporated. No systematic review or meta-analysis was performed.

\section{The Fatality of the COVID-I 9 Global Pandemic}

The COVID-19 pandemic has affected mankind with jetlike speed across the globe. As countries imposed strict lockdown policies on human movement with stay-home office activities, and most outstandingly, social distancing to halt the spread of the virus, thereby, all trade, commerce, financial and economic activities almost ceased. ${ }^{44,45}$ Currently, two-hundred-fifteen countries are affected around the planet. $^{3}$ The WORLDOMETER reported that $19,259,406$ confirmed cases of the COVID-19 existed. ${ }^{46}$ Our World in Data ${ }^{47}$ and WORLDOMETER ${ }^{46}$ revealed that till August 7, 2020, the COVID-19 related mortality was 707,715 (Figure 1) and 717,687 respectively [Scatterplot (Figure 2) illustrating daily vs, confirmed deaths, and new confirmed cases (Figure 3)].

At present, researchers worldwide are working hard to understand and develop COVID-19 viral physiology, epidemiology, and intervention strategies. ${ }^{4-51}$ Yet no specific medicine and vaccine targeting COVID-19 is available to safeguard mankind. ${ }^{52}$ It has been reported that COVID-19 replication potential is substantially speedier than any other infectious disease affecting human beings. ${ }^{53,54}$ Thereby, the COVID-19 has jeopardized almost all health care systems and health equity of our world, even of most affluent and developed countries ${ }^{55-58}$ The COVID-19 gained attention as the "great leveler" because it affects both rich and poor equally. ${ }^{59}$ Despite this, other studies reported that this COVID-19 pandemic has principally affected the USA's poorest people and is termed the "inequality virus". 58,60 Around $20 \%$ of diagnosed COVID-19 cases progress to clinically severe stages, affecting vital organs, and often end with multiple organ dysfunction. ${ }^{45}$ These patients require intensive care units, ventilation, and in some cases, extracorporeal membrane oxygenation (ECMO). ECMO supports bypassing the lung for oxygen and carbon dioxide exchange. ${ }^{61,62}$ In general, it has been observed that the COVID-19 patients aged over 60 -years with multiple comorbidities have a poorer prognosis and worse clinical outcomes. ${ }^{63,64}$ On the contrary, a smaller segment of the younger population suffers a high morbidity and mortality rate. ${ }^{53}$

\section{A Brief History of Convalescent Plasma Therapy}

Trauma-related bleeding is the top cause of death after injury and is considered preventable. ${ }^{65,66}$ Early transfusions of whole blood and fresh plasma are known to augment survival, alleviate the acute coagulopathy induced by physical injury, and restore the endothelial glycocalyx. ${ }^{67,68}$ Several plasma formulations are currently available worldwide. Those plasma formulations include fresh frozen plasma, thawed plasma, liquid plasma, plasma frozen within 24 hours, solvent-detergent plasma, and lyophilized plasma. ${ }^{69}$ A freeze-dried formulation of plasma termed as lyophilized plasma was initially introduced in clinical medicine during World War II in the 1930s by the American and British military $^{70,71}$, and is currently preferably used in parts of South Africa in a modern form. The concept of CPT is much older (since the 1800s) for the treatment of infectious disease. $^{5,72}$ The first-ever utilization of CPT was dated to 1892 for the management of diphtheria. Later the 1920s, CPT was used for scarlet fever and pertussis till $1970 .{ }^{5,73}$ It has been reported that CPT has been utilized during the 1918 Spanish flu pandemic with beneficial effects with some complications. $^{74}$

Furthermore, CPT has also been used in several viral diseases. Those viral ailments comprise measles, mumps, Argentine hemorrhagic fever, influenza, chickenpox, infections by cytomegalovirus, parvovirus B19, and, more of late, Middle East Respiratory Syndrome coronavirus (MERS-CoV), H1N1 and H5N1 avian flu, Ebola, and Severe Acute Respiratory Infections (SARIs) viruses. $^{5,72-78}$ Considering the fatal outcome of some of these viral diseases without therapeutic interventions, 
CPT's overall clinical outcome for viral infections was reasonably satisfactory.

\section{Initiation of Convalescent Plasma Therapy in the Management of the COVID-I 9}

Initially, research from two teams from the USA detailed the theoretical context for the employment of CPT in the management of COVID-19. ${ }^{79,80}$ Regarding collated reports until early July 2020, only two case series have been published. ${ }^{81,82}$ These revealed positively that there were changes in better oxygenation, sequential organ failure assessment (SOFA) scores, and ultimately, the need for ventilator use reduced. ${ }^{81,82}$ Although these were not welldesigned controlled studies; additionally, these patients had other medication along with $\mathrm{CPT}^{81,82}$ One Chinese study comprising one hundred and three patients compared CPT with standard treatment alone did not find a statistically significant beneficial effect within twenty-eight days. ${ }^{83}$ They also reported that the study was stopped prematurely. Thereby, the potential impacts of CPT might not be accurately reflected from the reported results. $^{83}$

\section{Mode of Plasma Therapy Infusion and Its Association with COVID- 19}

As illustrated (Figure 4), patients who recovered from COVID-19 had been regarded as a valuable donor source of CPT, and especially those recovered COVID-19 individuals with a high neutralizing antibody titer at or over 1:640 dilution. Subsequently there is a need to obtain more clarity to maximize the potential clinical benefits and minimize risks associated with convalescent blood products of the COVID-19. ${ }^{16,81,84}$ The use of CPT for patients with COVID-19 has been attributed to either preventing infection or reducing the disease severity. The convalescent serum is beneficial in a prophylactic mode as it can minimize virulence of ailments and illnesses by neutralization of antigen by specific antibodies that may arise in individuals who are at high risk of acquiring infections, thereby reducing the rate of mortality. ${ }^{79,85}$ Individuals with multiple comorbidities, elderly susceptible patients, and healthcare providers are the classic example of convalescent serum recipients for the COVID-19 current global pandemic with the intention of minimizing virulence and intensity of infection, symptoms, and mortality. Research has justified the above-mentioned use of convalescent serum, for example, with rabies viruses and hepatitis B treated with rabies immunoglobulin and hepatitis B immunoglobulin, respectively. ${ }^{86}$ Critics claim this approach's efficacy should be questioned, especially when there is no clinical trial evidence to support this concept. However, through historical facts and with clinical shreds of evidence, it is often predicted that the administration of convalescent antibodies is likely to show effectiveness in the prevention of diseases as opposed to the treatment of already established disease. ${ }^{79,85,86}$

Figure 4 depicts an individual who had COVID-19 but has recovered from this condition. Blood is drawn and then screened for virus-neutralizing antibodies. Those with high titers of neutralizing antibodies are identified. Thereafter an administration of serum containing these virus-neutralizing antibodies is given prophylactically to slow down progress or prevent infection in high-risk cases through neutralization of antigen by specific antibodies. ${ }^{87}$ As a last resort to improve survival with SARS-infection, the use of CPT has been widely accepted in recent times. ${ }^{88}$ Even though the use of passive antibody treatments has been recognized, there is a limited opinion that they should be used as initial therapies as opposed to their use against emerging and pandemic infectious threats.${ }^{74}$ In terms of additional value added by CPT, research claims that while its antibodies contribute to restrictions of viral replication, ${ }^{89}$ its other plasma components are beneficial in replenishing coagulation factors, especially for those patients with concurrent coagulopathy when they are given to patients with hemorrhagic fevers like Ebola. Notwithstanding these trends, individual CPT shows a donor-dependent variation in antibody specificities and titers. ${ }^{79,90,91}$

Considering that CPT is already being used in several diseases in general alongside its simplicity without adverse reactions, the evidence supplements the ideology that it can easily be used to treat individuals infected with COVID-19. Due to the increasing incidence, the quest to find a treatment for the SARS-Cov-2 pandemic remains a daunting challenge. Nevertheless, those patients who have recovered from COVID-19 are well suited to be capable of serum donors who can then be used for treating SARSCov-2 patients. The sample obtained can be stored and then used later when needed. Although it is often suggested that the potency of convalescent serum antiviral effects may not be completely reliable, they often show an increasingly significant variation. ${ }^{92}$ Overall, in the absence of specific therapy, CPT's use is likely to reduce disease severity positively. 


\section{Risk Factors and Safety Precautions Linked with CPT}

Several studies have been conducted to determine the safety and associated risks of convalescent plasma therapy for COVID-19 patients. $^{80,81,93,94}$ However, few reported any serious adverse effects of introducing CPT as a therapeutic measure for the COVID-19 pandemic. It is important to note that due to the sensitivity and idiosyncrasy attached to this matter, blood safety and quality must not be compromised for practical therapeutic approaches. Recognizing this fact, the focus on evaluating the risk associated with this therapy, particularly in vulnerable groups such as children, pregnant women, elderly individuals, and people with co-morbidities is essential.

Most of the studies conducted to determine the efficacy of CPT showed a significant reduction in viral load and relative risk of mortality. Generally, researchers hold the view that viremia mostly peaks in the first week of most viral infections. These patients then go on in the second week to develop a primary immune response, followed by either virus clearance or cytokine storm. Consequently, this trajectory could lead to multi-organ failure and, eventually, death. Taken together, CPT proponents have emphasized its usefulness by stating that CPT administration would be more effective in the very early stages of the disease, as confirmed in patients with SARS. ${ }^{95,96}$ The most common adverse reactions of CPT therapy are transfusionrelated events such as chills, fever, anaphylactic reactions, transfusion-related acute lung injury (TRALI), transfusionassociated circulatory overload (TACO), hemolysis, antibody-dependent enhancement (ADE), and transfusiontransmitted virus ${ }^{97,98}$ However, to date, it appears that the administration of convalescent plasma (CP) in COVID-19 cases is not associated with the onset of severe adverse effects. ${ }^{93}$ To obtain safe and very effective therapeutic results, donor-recipient screening with antibody titer (at least 1:160, standard 1:640) remains very crucial. However, other forms of selection are appropriate for COVID-19 patients in the CPT process. The CPT screening for COVID-19 patients includes testing for transfusion-transmission infections like human immunodeficiency virus (HIV), hepatitis B virus, and most importantly, the hepatitis $\mathrm{C}$ virus (since SARS-CoV-2 is a respiratory virus, it is not transmitted via blood and hence no risk of transmission from the donor). Similarly, human leukocyte antigen (HLA) antibody screening of female donors with a history of pregnancy tends to mitigate the risk of TRALI along with $\mathrm{ABO}$ blood compatibility testing. ${ }^{80,99,100}$

Biochemistry and blood profiles such as complete blood count and metabolic tests should be encouraged for the recipient's safety. Little or no evidence regarding the safe use of CP for vulnerable groups suffering from COVID-19 has been reported to date. Multiple studies reported that CPT among children with COVID-19 showed more positive recovery from the disease than adults without any adverse effects. ${ }^{80,101}$ In the same vein, the therapy conducted on critically ill patients with comorbid conditions involving a pregnant woman and elderly individuals showed an increased production of anti-SARS-CoV-2 IgG antibodies; hence, projected significant reduction of viral load alongside improved symptoms without showing adverse reactions. ${ }^{102}$ This same pattern was identified in a study conducted in Guinea that involved Ebola virus cases that were treated with CPT, which included 99 patients of various age groups (including eight pregnant women) who were recipients of ABO-compatible $\mathrm{CP}$ and infected with the Ebola virus. No severe adverse reactions resulted from this transfusion with (including the pregnant women and their fetuses). ${ }^{103}$

Furthermore, a study carried out on two elderly COVID19 patients with ARDS showed signs of improvement with no adverse reactions. ${ }^{104}$ Although adverse effects cannot be completely ruled out, a study of CPT conducted on ten ${ }^{79}$ COVID-19 patients showed improved recovery from the disease without severe adverse reactions. Hence, one of these patients faced minor side effects showing an evanescent facial red spot. ${ }^{81}$ Overall, despite the limitations of the current evidence, it may be inferred that CPT could be useful for the recovery of COVID-19 even among vulnerable age groups without having adverse effects on their health. This ideology helps to reiterate the fact that more studies to demonstrate the safety and efficacy of CPT among COVID19 patients are required, ${ }^{105-108}$, mainly when applied for both early and advanced phases of illness and prevention. ${ }^{109}$

\section{Recent Clinical Trials Regarding Convalescent Plasma Therapy in the Management of COVID-19}

Casadevall et al reported that therapeutic success against such a novel and complicated disease as COVID-19 involving multiple vital organs with a vast spectrum of signs and symptoms will necessitate more than one particular treatment strategy. ${ }^{110}$ Casadevall et al, ${ }^{110}$ commenting on the first randomized clinical trials of CPT 


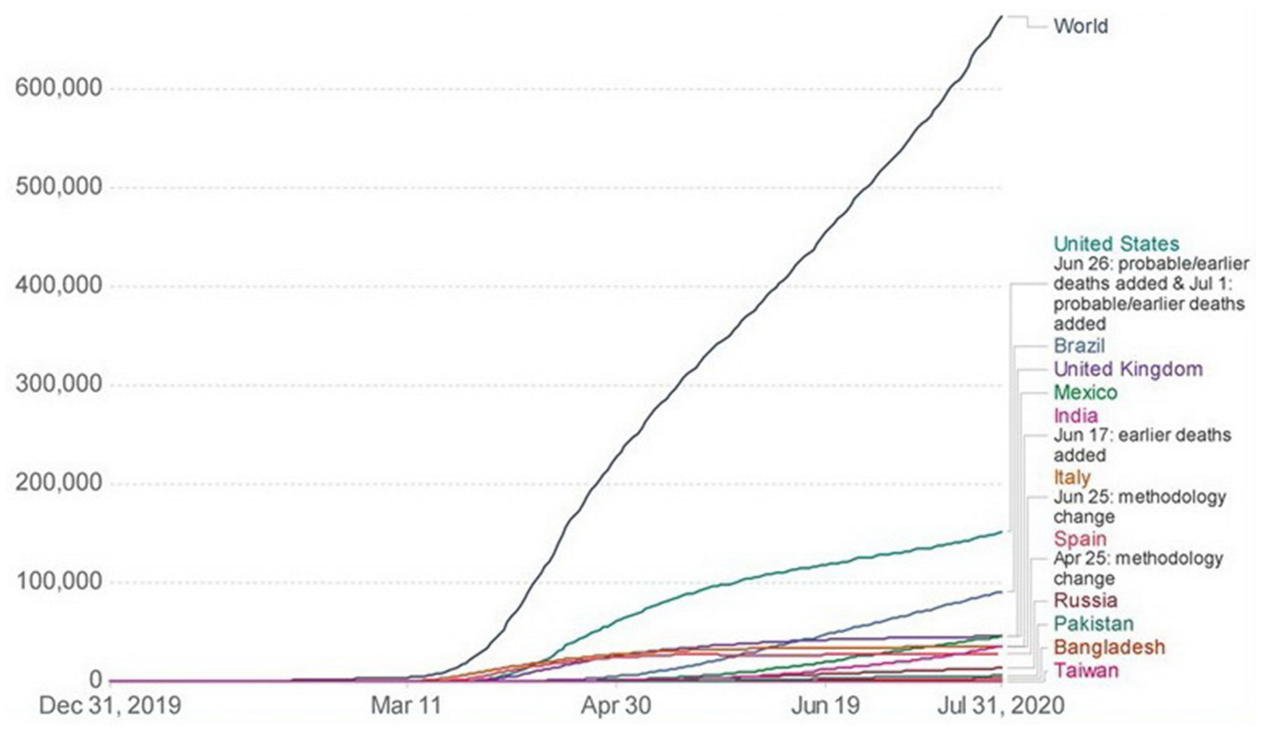

Figure I Cumulative confirmed COVID-19 deaths world and selected countries till July-3I-2020.

Notes: This figure is reproduced from Our World in Data. Statistics and Research. Coronavirus Pandemic (COVID-19). Available from: https://ourworldindata.org/ coronavirus. ${ }^{47}$

for COVID-19 patients in China, ${ }^{83}$ expressed a hope for plasma therapy or antibody administration the treatment options. Moreover, two studies have reported that COVID-19 convalescent plasma (CCP) transfusion improves outcome, including decreasing viral load, radiological findings improving pulmonary function, oxygenation level increase, and decreased mortality. ${ }^{81,82}$ These studies encouraged the US Food and Drug Administration (FDA) and the US blood-banking authorities to transfuse CCP on a record level. ${ }^{80}$ Thereby, in the USA alone, more than 26,000 COVID-19 patients received $\mathrm{CCP}$, primarily through the US government-run extended program. ${ }^{111}$ Additionally, multiple studies reported that CCP is well tolerated and possess no additional risk or adverse effects. ${ }^{112-115}$ COVID-19 brings a new research opportunity for CPT. Several clinical trials around the globe are ongoing to define the role of CPT. Furthermore, confirming the benefits of CPT will also enhance the progress regarding hyperimmune globulin and vaccine invention. However, the authors

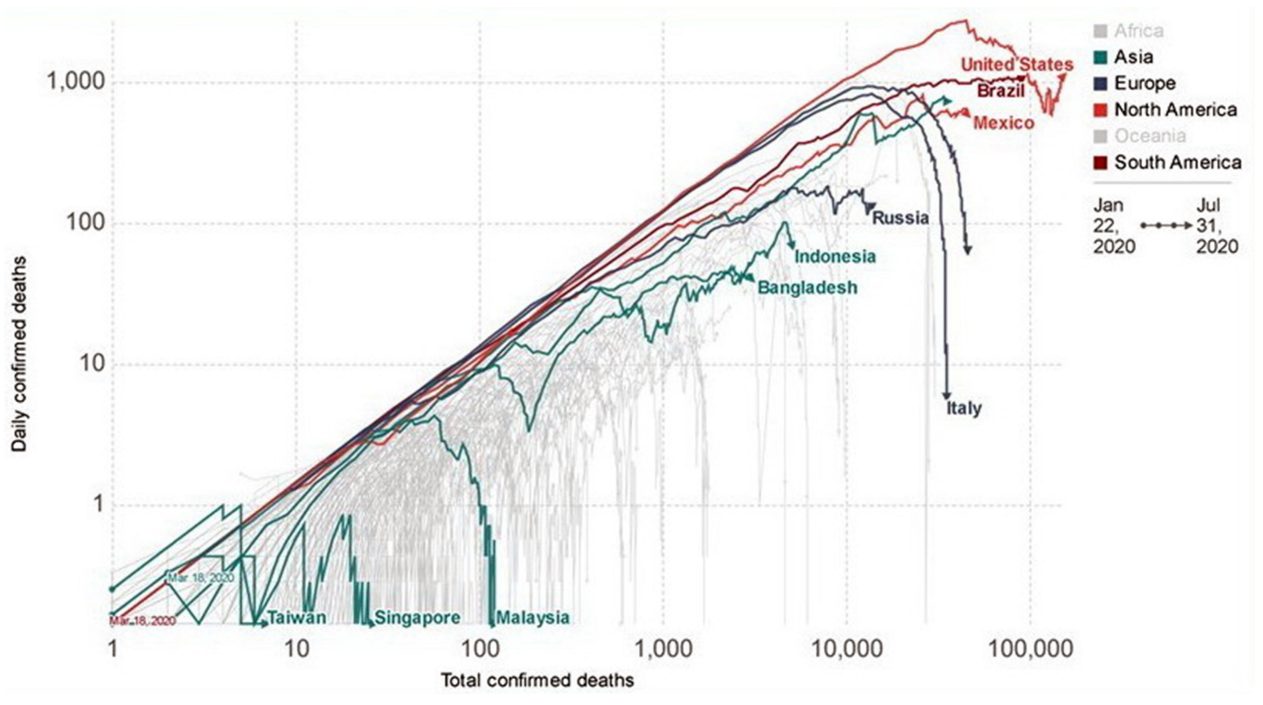

Figure 2 Scatterplot illustrating daily vs confirmed deaths due to COVID-19 cases of selected countries till July-3I-2020.

Notes: This figure is reproduced from Our World in Data. Statistics and Research. Coronavirus Pandemic (COVID-19). Available from: https://ourworldindata.org/ coronavirus. $^{47}$ 


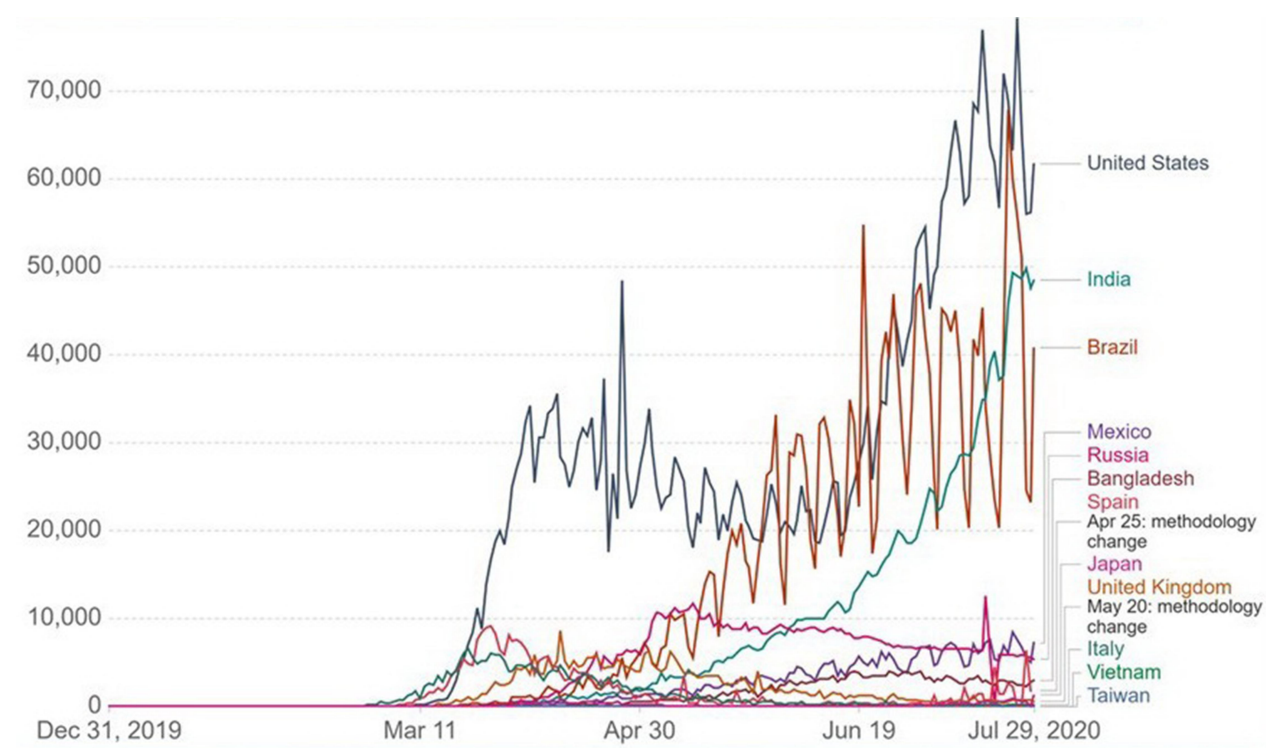

Figure 3 Daily new confirmed cases selected countries till July-3|-2020.

Notes: This figure is reproduced from Our World in Data. Statistics and Research. Coronavirus Pandemic (COVID-19). Available from: https://ourworldindata.org/ coronavirus. $^{47}$

recommended the need for coordination and synchronization of clinical trials to limit research challenges. ${ }^{11}$ There are 2630 clinical trials of COVID-19 that are currently registered by the World Health Organization. ${ }^{116}$ While COVID-19 appears as a significant public health challenge, may clinical trials were ongoing. ${ }^{117-119}$

\section{FDA Recommendation for the Use of Convalescent Plasma Therapy in COVID- 19}

The FDA on September-2-2020 pronounced a directive to offer endorsements to health care providers and investigators on the use of CCP under an emergency use authorization (EUA) or investigational CPT under an Investigational New Drug (IND) approval during the public health emergency. ${ }^{120}$ Full text of the recommendation of FDA regarding CCP is available from the link (https:// www.fda.gov/media/136798/download).

\section{CPT and the Potential of Microbial Transmission}

So far, CPT has been proven to have very minimal chances of transmitting infection to recipients due to the standard guidelines authorized by the Food and Drug Administration (FDA). Notwithstanding this, certain risks still exist. ${ }^{121}$ The possible risks associated with this transfusion include allergic reactions, damage to the lungs, and difficulty in breathing. Other fatal risks have been linked with the transmission of microbial infections such as HIV and Hepatitis B and C. ${ }^{123,124}$ Patient eligibility testing is a series of processes that involve the collection of relevant information from both the donor and recipient, which are then categorized and recorded for use. This data collection ultimately then helps to reduce the risk of the spread of various infections during blood transfusions. ${ }^{124-127}$

There is always that probability of an error occurring at any step of the transfusion process. The resulting effects in these situations can be fatal, so proper implementation of necessary safety measures should be taken. ${ }^{128}$ To ensure the appropriate donation of samples, the recruitment process tops the list. This aims to collect the blood correctly, to avoid wastage, and in a timely fashion. Pre-donation information is collated. Its goal is to protect both donor and recipient of these risk factors. The pre-donation details include interviews of the donor during collection, medical history, medication habits, any known risk factors, and traveling history. ${ }^{129}$ Information remains vital as the history of any self-administered drugs should also be listed, which should also be followed by the post-donation information, which aims to add to the involved patient's safety. This step will also include an examination of the body and screening for hemoglobin. ${ }^{130}$ The third and most sensitive section is the preparation and testing stage, which are to prepare and test 


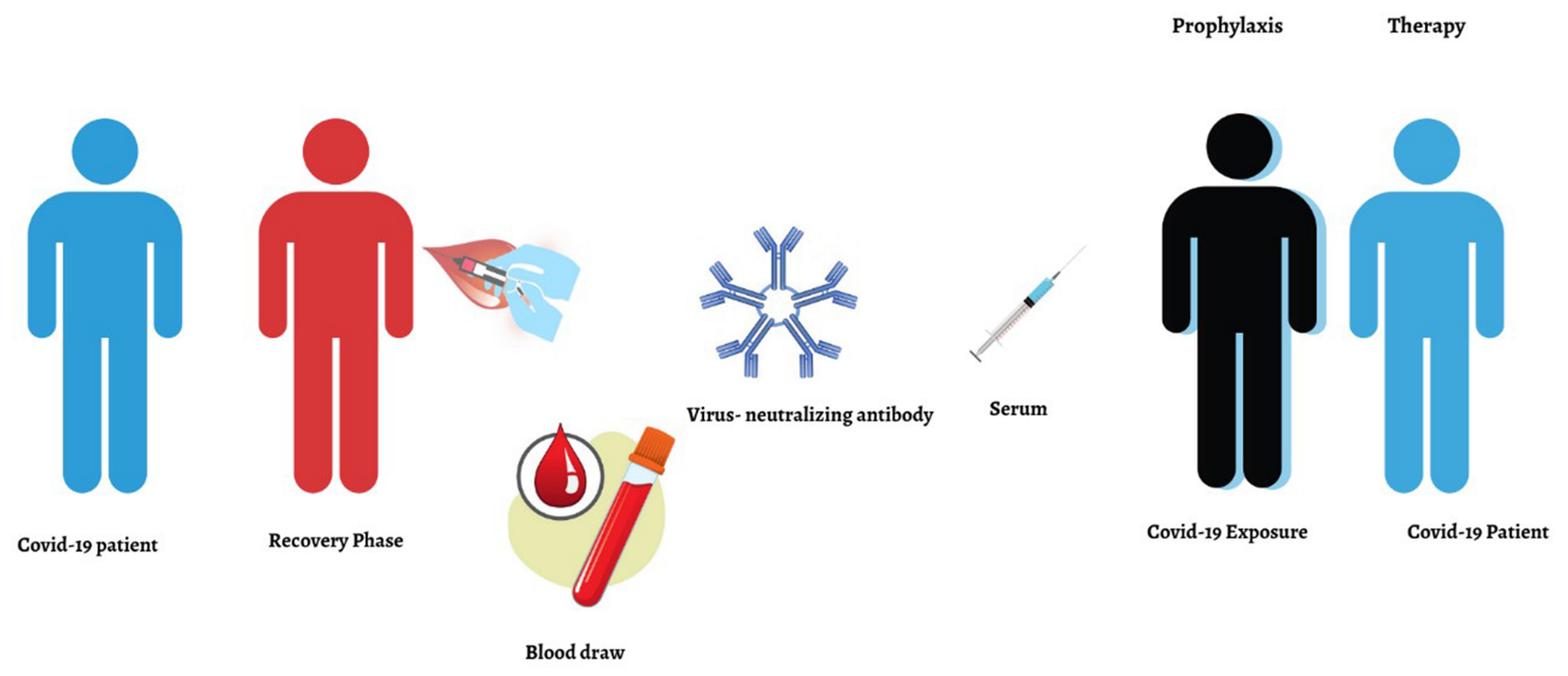

Figure 4 Infographics are showing the mode of convalescent plasma therapy for the treatment of COVID-19.

blood components on a donor's sample. The component testing mostly consists of disintegration, alteration, and quality check of samples, which entails the bacterial examination of the platelets, plasma separation, ${ }^{131}$ and pathogen inactivation ${ }^{132}$ In the donor testing step, along with blood grouping and antibody testing, serological and nucleic acid tests for sexually transmitted diseases and other viral infections are usually performed. ${ }^{131}$ Studies suggested pre-donation tests should include blood grouping and even screening for HCV, HIV, HBV, syphilis, and other locally spread diseases to reduce the risk of transferring other infections. ${ }^{133,134}$ Although serological and nucleic acid tests are more common in developed countries, the same procedures can be replicated elsewhere based on the commonality of the disease among many people and the accessibility of resources. ${ }^{135-138}$

Specific categories should be considered for eligibility and to maximize benefit, such as gender and pregnancy history, to avoid any complication or risks from ${ }^{139}$ procedures to cause minimal risk of transmitting infection. ${ }^{140}$ After completing these phases, it is vital to ensure that hospital management and clinical staff provide an aseptic transfusion. ${ }^{129}$ Furthermore, the blood collection process must follow best practice, using sterilized equipment for its collection and storage and employing trained personnel for these procedures. ${ }^{135-138}$ Similarly, other studies showed that there are risks to staff from infectious blood samples. ${ }^{141}$ Implementation of standardized safety measures ${ }^{142}$ and expertise that provides quality training and knowledge of these procedures' risks should be continuously integrated to ensure the safety of the health care workers. ${ }^{141}$

\section{Accessibility and Availability of CPT} Individuals who have recovered from COVID-19 are eligible to donate their plasma for infected individuals. ${ }^{143} \mathrm{~A}$ study conducted by Cameo and Lahoz showed that before the pandemic peaks the number of recovered patients at any specific period is usually far lower than the number of infected patients. They also referenced the fact that $1-5 \%$ of patients are receiving CPT. The leading cause of concern is typically the scarcity of donors and blood shortage. ${ }^{144}$ This has been further explained as surveys have shown that most individuals with COVID-19 are elderly people who sometimes have physical disabilities that prevent them from making donations. ${ }^{130}$ References can be discussed using some countries' profiles in terms of ongoing CPT. Although in Bangladesh, a lower-middleincome country, most affected patients with COVID-19 range from 21-40 years of age, along with inadequate testing, contact tracing, follow-up, and awareness have constrained the processes to identify affected people and collect blood samples from the recovered patients. ${ }^{145,146} \mathrm{It}$ would be better to create a central plasma bank to deliver plasma to emergency patients. ${ }^{147}$ Dhaka Medical College Hospital (DMCH), Bangladesh is one of the government hospitals situated in Dhaka, Bangladesh's capital that has pioneered collecting plasma from recovered patients and treating COVID-19 patients with CPT. It provides no-cost treatment to all patients. ${ }^{145,146}$

The plasma collection from donors involves the use of a particular kit worth BDT Taka 12,000/- (US\$142/-), and additional compulsory equipment is for the ALIZA test, 
which presents the number of antibodies in a donor's blood, which amounts to a total of BDT 1,50,000 (US \$1770) Each kit is aimed at testing only 90 patient samples. ${ }^{147}$ Considering this, it has become increasingly expensive to cater to the many COVID-19 patients through the national health coverage as Government hospitals have limited funds to finance this many people's treatment. On the contrary, a few private hospitals have provided plasma therapy and COVID-19 treatments but at very high costs. These variations of COVID-19 testing pricing projects inequality as private hospitals demand a higher price than public hospitals, which is not affordable for lowand middle-class individuals. ${ }^{147}$

To support the need for this treatment, a study conducted on COVID-19 patients within sub-Saharan Africa showed the effectiveness of CPT as it reduces the mortality rate by $50 \%$ compared to those who did not get CPT. Furthermore, this study also focused on reducing the treatment costs for patients, which ultimately increased their accessibility within the health care system and then cut the number of deaths. ${ }^{148}$ In China, CPT has shown a trend toward reduction of death rates. China can effectively combat this disease using CPT as they continually adapt testing strategies and understand its efficacy in saving these patients. ${ }^{149}$ Unfortunately, the public hospitals could not maintain this considerable pressure of testing and treatment so this might deter the quality of treatment obtainable in public hospitals. Due to the high influx of people who visit hospitals to get treatment, there is increased vulnerability to COVID-19 by healthy individuals. Also, in many cases, people cannot access treatment or testing from these clinics and may be left unattended, leading to fatalities. ${ }^{150-152}$ With the current global crisis this has affected income due to restrictions and loss of jobs, and the overall socio-economic condition has been detrimental to healthcare accessibility and affordability. ${ }^{153}$ If strategies are taken to make the therapy available, affordable, and accessible for general patients, similar to other previously occurring infectious diseases, COVID-19 mortality can also be addressed. ${ }^{93,154}$

\section{Efficacy as Well as Lack of Efficacy of CPT Treatment on COVID-19 Patients}

The COVID-19 expanded access program has been operating with the support of the U.S government through which plasma has been collected in support of recovered
COVID-19 patients. $^{81,155,156}$ It has been reported that more than 2500 sites for plasma collection, more than 12,000 physicians, and more than 70,000 patients were involved in this program. According to data from this program, more than 45,000 patients have received CPT. ${ }^{155,156}$ Having this considerable number of patients who have received CPT, studies have focused on different CPT aspects. A study indicated that CPT's efficacy in reducing mortality is somehow limited in cases of severely ill patients and those who have comorbidities. ${ }^{157}$ Besides, this study also showed less CPT efficiency for the patients treated on median day 21.5 during viral shedding.

Furthermore, the rate of recovery was poor in the case of the late transfusion of CPT. Among 21 patients, six of them got CPT and fifteen patients kept in the non-CPT (control) group to observe CPT's efficacy. After infusing the precise quantity of plasma, there were no significant side effects observed among the patients, but 5 of 6 patients died in the treatment group, and 14 of 15 died in the control group, although the treatment group had an extended survival period compared to the control group. Ultimately only one patient recovered from each group. ${ }^{157}$ On the other hand, another study was conducted on 1568 severely ill patients, where 1430 patients were under standard treatment, and 138 patients received $\mathrm{ABO}$-compatible CPT in a hospital in China to measure the efficacy of CPT. ${ }^{121}$ The result revealed that only three patients died (2.2\%) while another three (2.4\%) were admitted to ICU for a period in the CPT group. However, the number of patients admitted to ICU was higher (5.1\%) in the standard treatment group than the patients in the CPT group. ${ }^{158}$ Joyner et al studied 20,000 hospitalized patients in America, where they observed a seven-day mortality rate of COVID-19 affected patients after transfusing CP. ${ }^{114} \mathrm{~A}$ total of 1711 patients with COVID-19 died after receiving $\mathrm{CPT}$. In that case, the mortality rate was $8.56 \%$. Moreover, after receiving CPT, the mortality rate was higher in the case of severely ill patients, with $10.5 \%$ of patients admitted to ICU, $12.1 \%$ were mechanically ventilated, and $14.0 \%$ had either septic shock or multiple organ dysfunctions. ${ }^{114}$

\section{The Stability of Anti-COVID-19 Antibodies in Convalescent Plasma}

The therapeutic intention of CPT is to provide passive immunity to COVID-19 patients via antibodies. One earlier study examined physicochemical antibody stability 
under refrigerated conditions assessed using "turbidity, UV spectrometry, DLS, ion chromatography (CEX), gel exclusion chromatography (SEC), and light microscopy" and no signs of physicochemical alteration after seven days of storage at 4 or $25^{\circ} \mathrm{C}$ was found. ${ }^{159}$ However, slow oligomerization was noticed from day fifteen, however this was below $0.5 \%$. However, long-term impact was not evaluated by this study. ${ }^{159}$ One more study reported that antibody remains most stable in whole blood and plasma kept at $4{ }^{\circ} \mathrm{C}$, for seventy-two hours and five days, respectively, while being stable for at least a year in plasma kept at $-20{ }^{\circ} \mathrm{C}$. ${ }^{160}$

Additionally, another recent study revealed the longstanding constancy and steadiness of anti-COVID-19 antibodies among locally sourced donors CP samples collected from a local transfusion center. ${ }^{161}$ Another recent European study showed that the permanency and reliability of the anti-COVID-19-IgG neutralizing potential remain comprehensive $(100 \%)$ for $\mathrm{CP}$ preserved at $-30^{\circ}$ $\mathrm{C}$ for up to 9 days. ${ }^{162}$ That document commented that freshly collected CPT has potential in the management of COVID-19, especially in resource-limited countries. Health professionals should remember CPT only provides passive immunity for a brief period; the infused antibodies in the recipient only last a couple of weeks and will thus not induce immunity the same way a natural endogenous immune response (active immunity). ${ }^{5}$

\section{Effects of Convalescent Plasma on the Coagulopathy of COVID-I 9}

Coagulopathy is defined as any disorder of hemostasis.

The consequence is a combination of excessive bleeding or inappropriate clot formation, while most classically, coagulopathy is explained as a compromised clot development process. ${ }^{163}$ Multiple studies reported that severely ill COVID-19 patients with severe respiratory complications recurrently develop hypercoagulability, especially among hospitalized COVID-19 patients. These hypercoagulability patients develop microangiopathy, local and systemic coagulation disorders, pulmonary embolism, and organ failure. ${ }^{164-169}$ Raised D-Dimer levels were frequently reported among severe COVID-19 patients, correlated with poor prognosis and high mortality. ${ }^{169-171}$

Moreover, it has been observed among COVID-19 that prothrombin time (PT) and activated partial thromboplastin time (aPTT) often increases, fibrin degradation products increase, with severe thrombocytopenia leading to fatal disseminated intravascular coagulation (DIC), which demands relentless alertness, observance, and quick intervention. ${ }^{169,172}$ It has been reported that $\mathrm{CP}$ contains neutralizing antibodies, anti-inflammatory cytokines, clotting factors, natural antibodies, defensins, pentraxins, and other proteins obtained from recovered donors. ${ }^{173-175}$ Subsequently, the transfusion of $\mathrm{CP}$ to infected patients had a high possibility of providing additional clinical benefits through immunomodulation by inhibiting the severe inflammatory process. ${ }^{176-179}$

The mechanism of action $\mathrm{CP}$ in the management of COVID-19 has been categorized into two major groups: 1) immune, and 2) non-immune mechanism. ${ }^{180}$ Multiple reports documented that CP's most important immunerelated mode of action is by minimizing viral load through antibodies developed in recovered COVID-19 patients. ${ }^{113,181-184}$ A similar observation has been revealed among earlier viral epidemics. ${ }^{12,185-187}$ Additionally, another possible mechanism in neutralizing and suppressing viremia includes antibody-dependent cellular cytotoxicity, complement activation, and phagocytosis. ${ }^{188-190}$ Moreover, CP modifies the inflammatory responses of the COVID-19 disease process. The earlier transfusion of CP maximizes this beneficial effect, even for asymptomatic patients. ${ }^{82,115,191}$ Furthermore, CP has been reported to restore coagulation factors (the nonimmune related mechanism), thereby combating the coagulopathy induced by COVID-19. ${ }^{69,123}$

\section{Discussion}

Plasma from recovered patients from infectious microbial disease, predominantly after severe infection, possibly contains high levels of polyclonal, pathogen precise antibodies. ${ }^{5}$ These antibodies provide deliberate passive immunity to recipients with similar infection disorders. ${ }^{192}$ Convalescent plasma in viral pathogenic diseases are thought to act principally by neutralizing viral constituents. ${ }^{16} \mathrm{CPT}$, or purified antibodies from the plasma (hyperimmune globulin) of infected but recovered or well individuals, has been utilized in medical practice before the dawn of vaccines, including the influenza pandemic 1918. ${ }^{7,193,194}$ Hyperimmune globulin is defined as comparable to intravenous immunoglobulin (IVIG) apart from that it is organized from the plasma of recovered infected individuals with high titers of antibody counter to an exact microorganism or antigen. ${ }^{195,196}$ Hyperimmune globulin is currently used for post-exposure prophylaxis in the treatment of several viral 
infections, including hepatitis B (HBV), rabies, tetanus toxin, varicella-zoster, rubella, measles, etc. ${ }^{30,197-199}$ The COVID-19 pandemic attracted much new research to develop therapeutic drug options, ${ }^{200-203}$ including $\mathrm{CPT}^{80,88,93,102,113,204}$ to treat patients as no specific medication is available. Initially, the US FDA approved and served EUA, ${ }^{80,205}$ regarding CPT but later amended the earlier policy (September-2-2020). ${ }^{120}$ Multiple studies reported positively regarding the utilization of CCP transfusion among severe cases of COVID-19, particularly concerning CP safety and benefits. Nevertheless, almost all studies concluded the need for randomized, controlled clinical trials to assess CP efficacy and safety. ${ }^{104,206-211}$

It has been reported that COVID-19 has been a neglected issue in LMICs. ${ }^{212,213}$ Internationally, eight of the ten nations with the highest numbers of new cases of COVID-19 are upper middle income (Peru, Russia, South Africa, Argentina, Colombia, Mexico, Brazil) or lowermiddle-income states (India). ${ }^{212}$ It has been reported that in compassion to high-income countries (HICs), CCP transfusions have received scant attention in LMICs. ${ }^{213}$ Multiple reasons have been identified as the systemic challenges of resource-poor settings. Several LMICs do not possess a safe and reliable blood transfusion facility; this situation existed before COVID-19 due to poor donor enlistment and deployment, collections process, distribution, lack of infectious testing capability, and transfusion itself. $^{214-217}$ Against this background, CPT has been reported to reduce the need for ventilation among COVID-19 cases from LMICs. ${ }^{13,81,82}$ Another issue with CCP transfusion, especially in LMICs, is care to maintain proper ethical control of CCP transfusion and avert black market sales of $\mathrm{CCP} .^{214,218,219}$

\section{Conclusion}

In the past two decades, CPT has been successfully used to treat SARS, MERS, and H1N1 pandemic in 2009 with an acceptable level of safety and efficacy. The understanding that virological and clinical characteristics have been recognized to have similarities among SARS, MERS, and COVID-19, means that CPT may be a potential treatment option for the COVID-19 pandemic. Taking a critical look at strategies for available treatment, the patients who have recovered from SARS-CoV-2 infection could donate their plasma, which can then be transfused to the current COVID-19 positive severely ill patients, with the expectation that antibodies would reduce the severity of viral insult to the recipient vital organs. Studies from different countries have reported that CPT could significantly reduce the mortality rate of COVID-19 patients. ${ }^{107-109,121,122}$ Consequently, several countries around the globe are utilizing CPT for the management of COVID-19 patients and have achieved positive results. . $^{2,108,109,121-123}$ Therefore, to ensure maximum recovery from the severity of this pandemic, appropriate safety regarding transfusion and effective management of CPT's adverse effects should be considered.

\section{Recommendations}

COVID-19 is currently an enormous global public health crisis and is causing much misery in human life. ${ }^{220-222}$ Moreover, no specific anti-COVID-19 therapy is presently available for its management. ${ }^{115,162,203,223,224}$ Therefore, COVID-19 remains a significant threat to mankind. Given the gravity of the situation, CPT appears as an evolving defensive treatment option for near-fatal cases of COVID-19. ${ }^{81,82,225}$ Earlier studies reported that CPT had improved the survival rate among patients with several viral diseases, including SARS, MERS, influenza, Ebola virus disease, etc. ${ }^{226,227}$ The adverse reactions regarding CPT are reported as transfusion-related reactions. ${ }^{206,228}$ Although many limitations exist regarding CPT, nevertheless, considering the absence of specific treatments, CPT remains a viable option for treating COVID$19 .^{79,188,207,227,229,230}$

\section{Professionals Annotation}

The rapidly increasing incidence and death rates of COVID-19 cases remain continuously reported around the world. ${ }^{1}$ Currently, more than ten coronavirus vaccines are in the development phase, and the world is awaiting a breakthrough in research that will offer a medical solution for this devastating and detrimental pandemic. The foundation evidence-based preventive measures proved that their effectiveness in halting this virus's spread includes social distancing, personal hygiene, and face-protection with shields. These practices have helped about 29,925 172 (October 18, 2020) people across the world who were infected with the virus recover. ${ }^{231}$ The virus has changed the planet and affected the world at different levels, including demographic to economical, and triggered social and ethical dilemmas. The world is struggling with the unknown (ie, virus) and the uncertainty (ie, cure). The quest to find a treatment for the SARS-Cov-2 pandemic remains a daunting challenge. While some medicines, including hydroxychloroquine, Favipiravir, Remdesivir, and dexamethasone, have shown promise, they have not supported by randomized 
controlled studies. ${ }^{2,3}$ In view of these challenges, the adoption of traditional interventions has re-emerged as viable options in regulating this disease. ${ }^{4} \mathrm{~A}$ classic option has been the use of CPT. This method involves using apheresis in survivors with previous infections caused by pathogens of interest who have now developed antibodies against this causative agent. It is noteworthy to understand its history as surveys have linked its existence to the early 20th century in managing and preventing diseases alongside emergency interventions for various pandemics like the West Nile virus, Spanish flu, SARS-CoV, and, in recent times, the Ebola virus. ${ }^{5,-11}$ In recent times, reports undoubtedly claim that the use of CPT as a measure in curbing COVID-19 has been very vital, particularly in low-and middleincome countries, as people struggle to afford ventilators or abide by restriction policies over the long-term. ${ }^{13}$ Surprisingly, this virus has been deemed capable of replication at a substantially higher speed than other infectious diseases affecting humans. ${ }^{53,54}$ The virus is no respecter of persons as it affects both rich and poor individuals equally, which prompted its name as the "great leveller" ${ }^{59}$ Nevertheless, the pandemic has been detrimental to most health care systems and has negatively influenced health equity worldwide with an extension to people of affluence, even in western countries. ${ }^{55-58} \mathrm{On}$ the other hand, reports in the US have proposed that this global crisis has principally affected the community's poorest people. Thus, it has been termed as the "inequality virus" in these regions. ${ }^{58,60}$ Admittedly, studies that support the use of CPT as a measure for the COVID-19 virus remain minimal. A good example from a theoretical perspective was reported from the US, which detailed the use of CPT in the management of COVID-19 around early July 2020. During this period, only two case series were identified. ${ }^{79-82}$ Meanwhile, the findings showed a positive difference that resulted in better oxygenation, sequential organ failure assessment (SOFA) scores, and ultimately reduced need for ventilator use. ${ }^{81,82}$ Two major drawbacks of this study were that it was not a well-designed controlled study, and the CPT uptake was combined with the use of other medications. ${ }^{81,82}$ In furtherance to its advantageous nature, research claims that while its antibodies contribute to restrictions of viral replication, ${ }^{89}$ its other plasma components are beneficial in replenishing coagulation factors when they are given to patients with hemorrhagic fevers like Ebola. To obtain samples, patients free from COVID-19 are regarded as a valuable donor source for CPT, especially those having a high neutralizing antibody titer. It is important to note that due to the sensitivity and peculiarity attached to this matter, blood safety and quality must not be compromised for practical therapeutic approaches. Several studies have been conducted to determine the safety and associated risks of CPT for COVID-19 patients. ${ }^{80,81,93,94}$ However, only a few reported cases have mentioned any serious adverse effects of introducing CPT as a therapeutic measure for the COVID-19 pandemic. Recognizing this fact, the focus should be on the risk evaluation associated with this therapy, particularly in vulnerable groups such as children, pregnant women, elderly individuals, and people with co-morbidities. The most common adverse events from CPT are transfusion-related events such as chills, fever, anaphylactic reactions, TRALI, TACO, hemolysis, ADE, and transfusion-transmitted virus. ${ }^{97,98}$ The possible risks associated with this transfusion include allergic reactions, damage to the lungs, and difficulty in breathing. Other fatal risks have been linked with the transmission of microbial infections such as HIV and Hepatitis B and C. ${ }^{122,123}$ To reduce the risk of transferring other infections, studies suggested pre-donation tests should include blood grouping and even screening for HCV, HIV, HBV, syphilis, and other locally spread diseases. ${ }^{133,134}$ To obtain safe and very effective therapeutic results, donor-recipient screening remains very crucial. For instance, a study carried out on two elderly COVID-19 patients with ARDS showed signs of improvement and no adverse reactions. ${ }^{104}$ However, side effects cannot be completely ruled out, as another study of CPT conducted on ten ${ }^{79}$ COVID-19 patients showed improved recovery from the disease without severe adverse reactions. Hence, one of these patients faced minor side effects showing an evanescent facial red spot. ${ }^{81}$ Overall, despite the limitations surrounding CPT, it may be inferred that CPT is beneficial for recovering COVID19 persons even among vulnerable age groups. This ideology helps to reiterate the fact that more studies that demonstrate the safety and efficacy of CPT among COVID-19 patients are required $^{104-107}$ at the various phases of the illness and prevention. ${ }^{105-109}$

\section{Five to Ten Year Expectation Regarding Global Pandemic}

Pandemic is not a word to use lightly or carelessly. It is a word that, if misused, can cause unreasonable fear, or unjustified acceptance that the fight is over, leading to unnecessary suffering and death. ${ }^{232}$

The experience from earlier epidemics and pandemics has highlighted the critical role of robust primary health care supported by advanced tertiary care to combat the COVID-19 global pandemic. ${ }^{233-237}$ There is no vaccine, or specific antiviral agent, thus the control of the current pandemic is based on several prophylactic. Those 
preventive actions include detecting individuals affected with COVID-19 viral infection, ensuring medical care, following up on contacts, preparing healthcare facilities to deal with an influx of many patients, and training health professionals. $^{238}$ Multiple studies echo the WHO statement ${ }^{238}$ that health systems defensive capabilities are quite highly performing in Japan, Singapore, Hong Kong, Taiwan. Thereby, these countries' robust primary health care can manage much better than others. ${ }^{239-241}$ Singapore, Japan, Taiwan, and Hong Kong heavily invested in primary health care after the last epidemic of SARS. Thereby, the development of resilient and durable public health systems based on primary health care requires extensive support from all sectors of every country and must be capable of a range of interventions. ${ }^{242-244}$ Health-systems throughout the globe need to overhaul with lessons learned from the COVID-19 pandemic to minimize human misery.

"Researchers are searching for effective and suitable vaccine candidates and therapeutics for controlling the deadly COVID-19". ${ }^{245}$

It has been reported that the research risk of COVID19 remains high because of the potentially dangerous consequences among research volunteers. Additionally, critics state that if adverse consequences among research volunteers lead to life-threatening severe complications or death there is a high possibility of negative impacts on all challenging human-related research studies. As there is a potential harm when conducting these studies, national and international authorities should maintain excellent communication with their population by regularly updating the status of research, thereby minimizing potential repercussions. ${ }^{246}$ The scientific community is indeed putting a lot of effort into finding a way, and there is some progress regarding prevention, control, and treatment strategies of COVID-19. Nevertheless, the well-designed long-term clinical statistics on different therapeutic interventions for COVID-19 are rare. Additional studies have been recommended in suitable animal models for analyzing replication, transmission, and pathogenesis. ${ }^{245}$

Singapore confirmed its first COVID-19 case on January-23-2020, seven weeks (March 11-2020); later, WHO Director-General Dr. Tedros Adhanom Ghebreyesus announced the outbreak a Global Pandemic. ${ }^{247,248}$ Singapore has very high numbers of travelers because it is one of the top business hubs globally. Additionally, the country has an exceptional level of tourists, which include medical tourism. ${ }^{249-252}$ Thereby,
Singapore is particularly at risk of massive spreading and affecting its' population with the COVID-19. Nevertheless, on time, Singapore installed vigorous and assertive public health measures to avert the spread of the COVID-19. ${ }^{253}$ The country used their earlier experiences with the Severe Acute Respiratory Distress Syndrome (SARS) and the Influenza H1N1 pandemic epidemic in 2003 and 2009, respectively. ${ }^{253-256}$ It has been reported that Singapore's healthcare system had promptly recognized the COVID-19 public health threat and immediately responded to the disaster, based on a robust primary health care viewpoint. ${ }^{257-259}$ As the early symptoms and signs of the COVID-19 viral infection are broad-based, with many patients visiting primary health care clinics with mild upper respiratory tract symptoms. ${ }^{260,261}$

The healthcare system of Singapore is profoundly based on primary health care concepts and methods. ${ }^{262}$ The general practitioners (GPs) surgeries in Singapore are the first contact point for most diverse cases, and around $80 \%$ of total healthcare-seekers visited GP surgeries for primary health care daily. ${ }^{263}$ These GPs clinics also provide treatment for non-COVID-19 patients. Additionally, it protected them from the transmission of the COVID-19 during their visit to the surgeries. ${ }^{249}$ Furthermore, Singapore successfully also ensures healthcare professional safety and mitigates irrational fear, as they are the frontline fighters to maintain people's health. ${ }^{264}$ Thereby, GPs' health center remains the basis of initial spotting and segregation of suspected COVID19 victims within the large number of patients. ${ }^{249}$

Similarly, Taiwan controlled the pandemic of COVID19 more effectively than many other countries around the planet. ${ }^{240,265}$ The Taiwanese people entrusted the provision of a public healthcare system to supportive family doctors and community health care groups. Furthermore, a patient-centered integrated health care delivery system was established long-ago as an efficient solution to hazard in the medical care system. ${ }^{266-268}$ All these improvements in the Taiwanese healthcare system are based on primary health care. We are aware there are many issues in the development of vaccines or specific medicine for COVID19. We expect these research-related issues will be resolved by the next five to ten years' time. After that, the scientific community will able to provide a better solution for current or future such pandemics. This research finally projects in the next five to ten years there will be a massive change towards the improvement of public health care on the underlying primary health care 
concept, to effectively combat future epidemics and improve access and equity healthcare.

\section{Special Note}

Nevertheless, the Indian Council of Medical Research put out an open-label phase- 2 multicenter randomized controlled trial (placid trial) on October 22, 2020. Their research concluded CPT was unable to minimize COVID-19, both morbidity and mortality. ${ }^{269}$

\section{Article Highlights}

- CPT possesses the potential to reduce morbidity and mortality COVID-19.

- CPT induced side effects in treated patients, and riskbenefit assessment should identify potential recipients.

- If sensitivity is not maintained, possible health risks due to transfusion-associated contaminations overwhelm the benefits.

- The low ratio of cured cases to plasma donors leads to unavailability and inaccessibility.

\section{Acknowledgment}

The authors are grateful to Prof. Mohammed S. Razzaque, MBBS, Ph.D. of Lake Erie College of Osteopathic Medicine (Pennsylvania, USA) for providing useful suggestions. Additionally, the authors are very grateful to Professor (Dr.) Md Zakirul Islam, Professor, and VicePrincipal, Eastern Medical College, Cumilla, Bangladesh for his kind support to develop high-resolution figures.

\section{Author Contributions}

All authors made a significant contribution to the work reported, whether that is in the conception, study design, execution, acquisition of data, analysis, and interpretation, or in all these areas; took part in drafting, revising, or critically reviewing the article; gave final approval of the version to be published; have agreed on the journal to which the article has been submitted; and agree to be accountable for all aspects of the work.

\section{Funding}

This paper was not funded.

\section{Disclosure}

The authors report no conflicts of interest for this work. The authors declare that they do not have any financial involvement or affiliations with any organization, association, or entity which has a direct or indirect relationship with the subject matter or materials presented in this article. This also includes honoraria, expert testimony, employment, ownership of stocks or options, patents or grants received or pending, or royalties.

\section{References}

1. World Health Organization. WHO coronavirus disease (COVID19) dashboard. October 16, 2020. Available from: https://covid19. who.int/. Accessed October 17, 2020.

2. Haque MA, Akram L. Different management strategy of Covid19 patients. Bang $J$ Infect Dis. 2020;7:S51-S53. doi:10.3329/bjid. v7i0.46803

3. Horby P, Lim WS, Emberson JR, et al.; RECOVERY Collaborative Group. Dexamethasone in hospitalized patients with Covid-19 - preliminary report. $N$ Engl J Med. 2020: NEJMoa2021436. doi:10.1056/NEJMoa2021436

4. Wong HK, Lee CK. Pivotal role of convalescent plasma in managing emerging infectious diseases. Vox Sang. 2020;115(7):545547. doi:10.1111/vox.12927

5. Marano G, Vaglio S, Pupella S, et al. Convalescent plasma: new evidence for an old therapeutic tool? Blood Transfus. 2016;14 (2):152-157. doi:10.2450/2015.0131-15

6. Burnouf T, Seghatchian J. Ebola virus convalescent blood products: where we are now and where we may need to go. Transfus Apher Sci. 2014;51(2):120-125. doi:10.1016/j.transci.2014.10.003.

7. Mair-Jenkins J, Saavedra-Campos M, Baillie JK, et al.; Convalescent Plasma Study Group. The effectiveness of convalescent plasma and hyperimmune immunoglobulin for the treatment of severe acute respiratory infections of viral etiology: a systematic review and exploratory meta-analysis. $J$ Infect Dis. 2015;211(1):80-90. doi:10.1093/infdis/jiu396.

8. Rojas M, Monsalve DM, Pacheco Y, et al. Ebola virus disease: an emerging and re-emerging viral threat. $J$ Autoimmun. 2020;106:102375. doi:10.1016/j.jaut.2019.102375

9. Planitzer CB, Modrof J, Yu MY, Kreil TR. West Nile virus infection in plasma of blood and plasma donors, United States. Emerg Infect Dis. 2009;15(10):1668-1670. doi:10.3201/eid1510.081668.

10. Haley M, Retter A, Fowler D, Gea-Banacloche J, O'Grady N. The role for intravenous immunoglobulin in the treatment of West Nile virus encephalitis. Clin Infect Dis. 2003;37:e88-90. doi:10.1086/377172.

11. Shimoni Z, Niven M, Pitlick S, Bulvik S. Treatment of West Nile Virus encephalitis with intravenous immunoglobulin. Emerg Infect Dis. 2001;7(4):759. doi:10.3201/eid0704.017432.

12. van Griensven J, Edwards T, de Lamballerie X, et al. Evaluation of convalescent plasma for ebola virus disease in guinea. $N$ Engl $J$ Med. 2016;374(1):33-42. doi:10.1056/NEJMoa1511812

13. Syal K. COVID-19: herd immunity and convalescent plasma transfer therapy. J Med Virol. 2020;92(9):1380-1382. doi:10.1002/jmv.25870

14. Gayatri R, Lavanya S, Hussain M, Veslin J. The new pandemic Covid-19: treatment options and developments. Asian J Biol. 2020;9(3):1-13. doi:10.9734/AJOB/2020/v9i33008.

15. Corona Tracker. Bangladesh overview. August 7, 2020. Available from: https://www.coronatracker.com/country/bangla desh/. Accessed August 7, 2020.

16. Rojas M, Rodríguez Y, Monsalve DM, et al. Convalescent plasma in Covid-19: possible mechanisms of action. Autoimmun Rev. 2020;19(7):102554. doi:10.1016/j.autrev.2020.102554

17. Tamburello A, Marando M. Immunoglobulins or convalescent plasma to tackle COVID-19: buying time to save lives - current situation and perspectives. Swiss Med Wkly. 2020;150:w20264. doi:10.4414/smw.2020.20264 
18. Casadevall A, Pirofski LA. The convalescent sera option for containing COVID-19. J Clin Invest. 2020;130(4):1545-1548. doi:10.1172/JCI138003.

19. Sawyer LA. Antibodies for the prevention and treatment of viral diseases. Antiviral Res. 2000;47(2):57-77. doi:10.1016/s01663542(00)00111-x.

20. Seghatchian J, Lanza F. Convalescent plasma, an apheresis research project targeting and motivating the fully recovered COVID 19 patients: a rousing message of clinical benefit to both donors and recipients alike. Transfus Apher Sci. 2020;59 (3):102794. doi:10.1016/j.transci.2020.102794.

21. Chua Vi Long K, Sayed A, Karki P, Acharya Y. Convalescent blood products in COVID-19: a narrative review. Ther Adv Infect Dis. 2020;7:2049936120960646. doi:10.1177/2049936120960646

22. Drexler M Institute of Medicine (US). What you need to know about infectious disease. Washington (DC): National Academies Press (US); 2010. IV, Prevention, and Treatment. Available from: https://www. ncbi.nlm.nih.gov/books/NBK209704/. Accessed October 15, 2020.

23. Clem AS. Fundamentals of vaccine immunology. J Glob Infect Dis. 2011;3(1):73-78. doi:10.4103/0974-777X.77299.

24. Piyush R, Rajarshi K, Khan R, Ray S. Convalescent plasma therapy: a promising coronavirus disease 2019 treatment strategy. Open Biol. 2020;10(9):200174. doi:10.1098/rsob.200174.

25. Pulendran B, Ahmed R. Translating innate immunity into immunological memory: implications for vaccine development. Cell. 2006;124(4):849-863. doi:10.1016/j.cell.2006.02.019.

26. InformedHealth.org [Internet]. Cologne, Germany: Institute for Quality and Efficiency in Health Care (IQWiG); 2006. How does the immune system work? [Updated April 23, 2020]. Available from: https://www.ncbi.nlm.nih.gov/books/ NBK279364/. Accessed October 16, 2020.

27. Klimpel GR. Immune defenses. In: Baron S, editor. Medical Microbiology. 4th edition ed. Galveston: University of Texas Medical Branch at Galveston; 1996. Chapter 50. Available from: https://www.ncbi.nlm.nih.gov/books/NBK8423/. Accessed October 16, 2020.

28. Nicholson LB. The immune system. Essays Biochem. 2016;60 (3):275-301. doi:10.1042/EBC20160017

29. Raab CP. Passive immunization. Prim Care. 2011;38(4):681-91, viii. doi:10.1016/j.pop.2011.07.006.

30. Slifka MK, Amanna IJ. Passive immunization. Plotkin's Vaccines. 2018;84-95. e10. doi:10.1016/B978-0-323-35761-6.00008-0

31. Graham BS, Ambrosino DM. History of passive antibody administration for prevention and treatment of infectious diseases. Curr Opin HIV AIDS. 2015;10(3):129-134. doi:10.1097/ COH.0000000000000154

32. Hey A. History and practice: antibodies in infectious diseases. Microbiol Spectr. 2015;3(2):AID-0026-2014. PMID: 26104697. doi:10.1128/microbiolspec.AID-0026-2014.

33. Casadevall A, Scharff MD. Return to the past: the case for antibody-based therapies in infectious diseases. Clin Infect Dis. 1995;21(1):150-161. doi:10.1093/clinids/21.1.150.

34. Casadevall A, Dadachova E, Pirofski LA. Passive antibody therapy for infectious diseases. Nat Rev Microbiol. 2004;2(9):695703. doi:10.1038/nrmicro974.

35. Bracha A, Tan SY. Emil von Behring (1854-1917): medicine's first Nobel laureate. Singapore Med J. 2011;52(1):1-2. PMID: 21298232.

36. Winau F, Winau R. Emil von Behring, and serum therapy. Microbes Infect. 2002;4(2):185-188. doi:10.1016/s1286-4579(01)01526-X.

37. Behring E, Kitasato S. Über das Zustandekommen der DiphtherieImmunität und der Tetanus-Immunität bei Thieren [On the development of immunity to diphtheria and tetanus in animals]. Dtsch Med Wochenschr. 1890;16:1113-1114. doi:10.1055/s-0029-1207589
38. Pucca MB, Cerni FA, Janke R, et al. History of envenoming therapy and current perspectives. Front Immunol. 2019;10:1598. doi:10.3389/fimmu.2019.01598.

39. Robbins JB, Schneerson R, Szu SC. Perspective: hypothesis: serum IgG antibody is sufficient to confer protection against infectious diseases by inactivating the inoculum. J Infect Dis. 1995;171(6):1387-1398. doi:10.1093/infdis/171.6.1387.

40. Beigel JH, Voell J, Kumar P, et al. Safety and tolerability of a novel, polyclonal human anti-MERS coronavirus antibody produced from transchromosomic cattle: a Phase 1 randomized, double-blind, single-dose-escalation study. Lancet Infect Dis. 2018;18(4):410-418. doi:10.1016/S1473-3099(18)30002-1.

41. Shamim S, Khan M, Kharaba ZJ, Ijaz M, Murtaza G. Potential strategies for combating COVID-19. Arch Virol. 2020;165 (11):2419-2438. doi:10.1007/s00705-020-04768-3

42. Casadevall A, Pirofski LA. Antibody-mediated regulation of cellular immunity and the inflammatory response. Trends Immunol. 2003;24(9):474-478. doi:10.1016/s1471-4906(03)00228-x.

43. Forthal DN. Functions of Antibodies. Microbiol Spectr. 2014;2 (4):1-17.

44. The World Bank. The Global Economic Outlook during the COVID-19 pandemic: a changed world; 2020. Available from: https://www.worldbank.org/en/news/feature/2020/06/08/the-glo bal-economic-outlook-during-the-covid-19-pandemic-a-changedworld. Accessed July 31, 2020.

45. Anwar S, Nasrullah M, Hosen MJ. COVID-19 and Bangladesh: challenges and how to address them. Front Public Health. 2020;8:154. doi:10.3389/fpubh.2020.00154

46. WORLDOMETER. COVID-19 Coronavirus Pandemic; 2020 Available from: https://www.worldometers.info/coronavirus/? utm campaign=homeAdvegas 1?\%22. Accessed July 31, 2020.

47. Ritchie H, Ortiz-Ospina E, Beltekian D, et al. Coronavirus Pandemic (COVID-19) - the data; 2020. Available from: https:// ourworldindata.org/coronavirus-data. Accessed July 31, 2020.

48. Cascella M, Rajnik M, Cuomo A, et al. Features, Evaluation and Treatment Coronavirus (COVID-19) [Updated 2020 Jul 4]. In: StatPearls [Internet]. Treasure Island (FL): StatPearls Publishing; 2020. Available from: https://www.ncbi.nlm.nih.gov/books/ NBK554776/. Accessed August 1, 2020.

49. Ashour HM, Elkhatib WF, Rahman MM, Elshabrawy HA. Insights into the recent 2019 novel Coronavirus (SARS-CoV-2) in light of past human Coronavirus outbreaks. Pathogens. 2020;9 (3):186. doi:10.3390/pathogens9030186

50. Meo SA, Alhowikan AM, Al-Khlaiwi T, et al. Novel coronavirus 2019-nCoV: prevalence, biological and clinical characteristics comparison with SARS-CoV and MERS-CoV. Eur Rev Med Pharmacol Sci. 2020;24(4):2012-2019. doi:10.26355/eurrev_202002_20379

51. Escalera-Antezana JP, Lizon-Ferrufino NF, Maldonado-Alanoca A, et al. Clinical features of the first cases and a cluster of Coronavirus Disease 2019 (COVID-19) in Bolivia imported from Italy and Spain. Travel Med Infect Dis. 2020;35:101653. doi:10.1016/j.tmaid.2020.101653

52. Jiang S. Don't rush to deploy COVID-19 vaccines and drugs without sufficient safety guarantees. Nature. 2020;579 (7799):321. doi:10.1038/d41586-020-00751-9

53. Yi Y, Lagniton PNP, Ye S, Li E, Xu RH. COVID-19: what has been learned and to be learned about the novel coronavirus disease. Int J Biol Sci. 2020;16(10):1753-1766. doi:10.7150/ ijbs.45134

54. Mas-Coma S, Jones MK, Marty AM. COVID-19 and globalization. One Health. 2020;9:100132. doi:10.1016/j.onehlt.2020.100132

55. Shadmi E, Chen Y, Dourado I, et al. Health equity and COVID19: global perspectives. Int J Equity Health. 2020;19(1):104. doi:10.1186/s12939-020-01218-z

56. Wang Z, Tang K. Combating COVID-19: health equity matters. Nat Med. 2020;26(4):458. doi:10.1038/s41591-020-0823-6 
57. Ramirez-Valles J, Breton E, Chae DH, Haardörfer R, Kuhns LM. The COVID-19 pandemic: everything old is new again in public health education. Health Educ Behav. 2020;47(4):501-503. doi:10.1177/1090198120935067

58. Ali S, Asaria M, Stranges S. COVID-19, and inequality: are we all in this together? Can J Public Health. 2020;111(3):415-416. doi:10.17269/s41997-020-00351-0

59. Milne A UK under fire for suggesting coronavirus 'great leveler.' Reuters; 2020. Available from: https://www.reuters.com/article/ us-health-coronavirus-leveller-trfn/uk-under-fire-for-suggestingcoronavirus-great-leveller-idUSKCN21R30P. Accessed August 1, 2020.

60. McGreal $\mathrm{C}$ The inequality virus: how the pandemic hit America's poorest. The Guardian; 2020. Available from: https://www.the guardian.com/world/2020/apr/09/america-inequality-laid-bare-cor onavirus. Accessed August 1, 2020.

61. Nakamura K, Hikone M, Shimizu H, et al. A sporadic COVID-19 pneumonia treated with extracorporeal membrane oxygenation in Tokyo, Japan: a case report. J Infect Chemother. 2020;26(7):756761. doi:10.1016/j.jiac.2020.03.018

62. Zeng Y, Cai Z, Xianyu Y, Yang BX, Song T, Yan Q. Prognosis when using extracorporeal membrane oxygenation (ECMO) for critically ill COVID-19 patients in China: a retrospective case series. Crit Care. 2020;24(1):148. doi:10.1186/s13054-020-2840-8

63. Liu K, Chen Y, Lin R, Han K. Clinical features of COVID-19 in elderly patients: a comparison with young and middle-aged patients. J Infect. 2020;80(6):e14-e18. doi:10.1016/j.jinf.2020.03.005

64. Sanyaolu A, Okorie C, Marinkovic A, et al. Comorbidity and its Impact on Patients with COVID-19. SN Compr Clin Med. 2020:1-8. doi:10.1007/s42399-020-00363-4.

65. Gholipour C, Rad BS, Vahdati SS, Ghaffarzad A, Masoud A. Evaluation of preventable trauma death in emergency department of Imam Reza hospital. World J Emerg Med. 2016;7(2):135-137. doi:10.5847/wjem.j.1920-8642.2016.02.009

66. Eastridge BJ, Holcomb JB, Shackelford S. Outcomes of traumatic hemorrhagic shock and the epidemiology of preventable death from injury. Transfusion. 2019;59(S2):1423-1428. doi:10.1111/trf.15161

67. Barelli S, Alberio L. The role of plasma transfusion in massive bleeding: protecting the endothelial glycocalyx? Front Med (Lausanne). 2018;5:91. doi:10.3389/fmed.2018.00091

68. Simmons JW, Pittet JF, Pierce B. Trauma-Induced Coagulopathy. Curr Anesthesiol Rep. 2014;4(3):189-199. doi:10.1007/s40140014-0063-8

69. Nair PM, Rendo MJ, Reddoch-Cardenas KM, Burris JK, Meledeo MA, Cap AP. Recent advances in use of fresh frozen plasma, cryoprecipitate, immunoglobulins, and clotting factors for transfusion support in patients with hematologic disease. Semin Hematol. 2020;57(2):73-82. doi:10.1053/j.seminhematol.2020.07.006

70. Gokhale SG, Scorer T, Doughty H. Freedom from frozen: the first British military use of lyophilized plasma in forward resuscitation. J R Army Med Corps. 2016;162(1):63-65. doi:10.1136/ jramc-2014-000361

71. Inaba K. Freeze-dried plasma. J Trauma. 2011;70(5 Suppl):S57S58. doi:10.1097/TA.0b013e31821a6057

72. Sridevi K, Munjal A, Chandran A, et al. Convalescent plasma therapy for prophylaxis and treatment of COVID-19: a systematic research of facts and files, a narrative review. Ann Clin Lab Res. 2020;8(2):314.

73. The American Society for Microbiology. The toxin-based diseases common in North America during the 1600-1700s; 2019. Available from: https://asm.org/Articles/2019/July/The-Toxin-BasedDiseases-Common-in-North-America-d. Accessed August 1, 2020.

74. Leider JP, Brunker PA, Ness PM. Convalescent transfusion for pandemic influenza: preparing blood banks for a new plasma product? Transfusion. 2010;50(6):1384-1398. doi:10.1111/ j.1537-2995.2010.02590.x
75. WHO Mers-Cov Research Group. State of knowledge and data gaps of middle east respiratory syndrome Coronavirus (MERSCoV) in Humans. PLoS Curr. 2013;5:ecurrents. outbreaks. doi:10.1371/currents.

outbreaks.0bf719e352e 7478f8ad85fa30127ddb8

76. Zingher A, Mortimer P. Convalescent whole blood, plasma, and serum in the prophylaxis of measles: JAMA, 12 April 1926; 1180-1187. Rev Med Virol. 2005;15(6):407-421. doi:10.1002/ rmv.480

77. Young MK, Nimmo GR, Cripps AW, Jones MA. ost-exposure passive immunization for preventing measles. Cochrane Database Syst Rev. 2014;4:CD010056. doi:10.1002/14651858. CD010056.pub2

78. Beigel JH, Luke TC. A study in scarlet-convalescent plasma for severe influenza*. Crit Care Med. 2012;40(3):1027-1028. doi:10.1097/CCM.0b013e31823d77c3

79. Montelongo-Jauregui D, Vila T, Sultan AS, Jabra-Rizk MA. Convalescent serum therapy for COVID-19: a 19th-century remedy for a 21st-century disease. PLoS Pathog. 2020;16(8): e1008735. doi:10.1371/journal.ppat.1008735

80. Bloch EM, Shoham S, Casadevall A, et al. Deployment of convalescent plasma for the prevention and treatment of COVID-19. J Clin Invest. 2020;130(6):2757-2765. doi:10.1172/JCI138745

81. Duan K, Liu B, Li C, et al. Effectiveness of convalescent plasma therapy in severe COVID-19 patients. Proc Natl Acad Sci USA. 2020;117(17):9490-9496. doi:10.1073/pnas.2004168117

82. Shen C, Wang Z, Zhao F, et al. Treatment of 5 Critically Ill Patients With COVID-19 With Convalescent Plasma. JAMA. 2020;323(16):1582-1589. doi:10.1001/jama.2020.4783

83. Li L, Zhang W, Hu Y, et al. Effect of Convalescent Plasma Therapy on Time to Clinical Improvement in Patients With Severe and Life-threatening COVID-19: a Randomized Clinical Trial. JAMA. 2020;324(5):460-470. doi:10.1001/jama.2020. 10044

84. Langhi DM Jr, Santis GC, Bordin JO. COVID-19 convalescent plasma transfusion. Hematol Transfus Cell Ther. 2020;42(2):113115. doi:10.1016/j.htct.2020.04.003

85. Diep BA, Le VT, Badiou C, et al. IVIG-mediated protection against necrotizing pneumonia caused by MRSA. Sci Transl Med. 2016;8(357):357ra124. doi:10.1126/scitranslmed.a g1153

86. Luke T, Casadevall A, Watowich S, Hoffman S, Beigel J, Burgess TH. Hark back: passive immunotherapy for influenza and other serious infections. Crit Care Med. 2010;38(4 suppl):e66-e73. doi:10.1097/CCM.0b013e3181d44c1e

87. Al-Riyami AZ, Schäfer R, van der Berg K, et al. Clinical use of Convalescent Plasma in the COVID-19 pandemic; a transfusionfocused gap analysis with recommendations for future research priorities. Vox Sang. 2020. doi:10.1111/vox.12973

88. Tanne JH. Covid-19: FDA approves use of convalescent plasma to treat critically ill patients. $B M J .2020 ; 368: \mathrm{m} 1256$. doi:10.1136/ bmj.m1256

89. Zhang L, Pang R, Xue X, et al. Anti-SARS-CoV-2 virus antibody levels in convalescent plasma of six donors who have recovered from COVID-19. Aging (Albany NY). 2020;12(8):6536-6542. doi:10.18632/aging.103102

90. Kumar GV, Jeyanthi V, Ramakrishnan S. A short review on antibody therapy for COVID-19. New Microbes New Infect. 2020;35:100682. doi:10.1016/j.nmni.2020.100682

91. Uyeki TM, Mehta AK, Davey RT Jr, et al. Clinical Management of Ebola Virus Disease in the United States and Europe. $N$ Engl $J$ Med. 2016;374(7):636-646. doi:10.1056/NEJMoa1504874

92. Kraft CS, Hewlett AL, Koepsell S, et al. The Use of TKM100802 and Convalescent Plasma in 2 Patients with Ebola Virus Disease in the United States. Clin Infect Dis. 2015;61(4):496502. doi:10.1093/cid/civ334 
93. Chen L, Xiong J, Bao L, Shi Y. Convalescent plasma as a potential therapy for COVID-19. Lancet Infect Dis. 2020;20 (4):398-400. doi:10.1016/S1473-3099(20)30141-9s

94. Ye M, Fu D, Ren Y, et al. Treatment with convalescent plasma for COVID-19 patients in Wuhan, China. J Med Virol. 2020. doi:10.1002/jmv.25882

95. Cheng Y, Wong R, Soo YO. Use of convalescent plasma therapy in SARS patients in Hong Kong. Eur J Clin Microbiol Infect Dis. 2005;24:44-46. doi:10.1007/s10096-004-1271-9

96. Soo YO, Cheng Y, Wong R, et al. Retrospective comparison of convalescent plasma with continuing high-dose methylprednisolone treatment in SARS patients. Clin Microbiol Infect. 2004;10 (7):676-678. doi:10.1111/j.1469-0691.2004.00956.x

97. Luke TC, Kilbane EM, Jackson JL, Hoffman SL. Meta-analysis: convalescent blood products for Spanish influenza pneumonia: a future H5N1 treatment? Ann Intern Med. 2006;145(8):599-609. doi:10.7326/0003-4819-145-8-200610170-00139

98. MacLennan S, Barbara JA. Risks and side effects of therapy with plasma and plasma fractions. Best Pract Res Clin Haematol. 2006;19(1):169-189. doi:10.1016/j.beha.2005.01.033

99. Epstein J, Burnouf T. Points to consider in the preparation and transfusion of COVID-19 convalescent plasma. Vox Sang. 2020. doi:10.1111/vox.12939

100. Hardcastle TC. Complications of massive transfusion in trauma patients. ISBT Sci Ser. 2006;1:180-184. doi:10.1111/j.17512824.2006.00027.x

101. Malani AN, Sherbeck JP, Malani PN. Convalescent Plasma and COVID-19. JAMA. 2020;324(5):524. doi:10.1001/jama.2020.10699

102. Rajendran K, Krishnasamy N, Rangarajan J, Rathinam J, Natarajan M, Ramachandran A. Convalescent plasma transfusion for the treatment of COVID-19: systematic review. J Med Virol. 2020. doi:10.1002/jmv.25961

103. van Griensven J, Edwards T, Baize S; Ebola-Tx Consortium. Efficacy of convalescent plasma in relation to dose of ebola virus antibodies. $N$ Engl J Med. 2016;375(23):2307-2309. doi:10.1056/NEJMc1609116

104. Ahn JY, Sohn Y, Lee SH, et al. Use of convalescent plasma therapy in two COVID-19 patients with acute respiratory distress syndrome in Korea. J Korean Med Sci. 2020;35(14):e149. doi:10.3346/jkms.2020.35.e149

105. Zhang B, Liu S, Tan T, et al. Treatment with convalescent plasma for critically Ill patients with severe acute respiratory syndrome coronavirus 2 infection. Chest. 2020;158(1):e9-e13. doi:10.1016/ j.chest.2020.03.039

106. Zhang J, Xie B, Hashimoto K. Current status of potential therapeutic candidates for the COVID-19 crisis. Brain Behav Immun. 2020;87:59-73. doi:10.1016/j.bbi.2020.04.046

107. Devasenapathy N, Ye Z, Loeb M, et al. Efficacy and safety of convalescent plasma for severe COVID-19 based on evidence in other severe respiratory viral infections: a systematic review and meta-analysis. CMAJ. 2020;192(27):E745-E755. doi:10.1503/ cmaj.200642

108. Tiberghien P, de Lamballerie X, Morel P, Gallian P, Lacombe K, Yazdanpanah Y. Collecting and evaluating convalescent plasma for COVID-19 treatment: why and how? Vox Sang. 2020;115 (6):488-494. doi:10.1111/vox.12926

109. Barone P, DeSimone RA. Convalescent plasma to treat coronavirus disease 2019 (COVID-19): considerations for clinical trial design. Transfusion. 2020;60(6):1123-1127. doi:10.1111/ trf. 15843

110. Casadevall A, Joyner MJ, Pirofski LA. A randomized trial of convalescent plasma for COVID-19-potentially hopeful signals. JAMA. 2020;324(5):455-457. doi:10.1001/jama.2020.10218

111. Bloch EM. Convalescent plasma to treat COVID-19. Blood. 2020;136(6):654-655. PMID: 32761219; PMCID: PMC7414 591. doi:10.1182/blood.2020007714.
112. Joyner MJ, Wright RS, Fairweather D, et al. Early safety indicators of COVID-19 convalescent plasma in 5000 patients. J Clin Invest. 2020;130(9):4791-4797. PMID: 32525844; PMCID: PMC7456238. doi:10.1172/JCI140200.

113. Brown BL, McCullough J. Treatment for emerging viruses: convalescent plasma and COVID-19. Transfus Apher Sci. 2020;59 (3):102790. PMID: 32345485; PMCID: PMC7194745. doi:10.1016/j.transci.2020.102790.

114. Joyner MJ, Bruno KA, Klassen SA, et al. Safety update: COVID-19 convalescent plasma in 20,000 hospitalized patients. Mayo Clin Proc. 2020;95(9):1888-1897. doi:10.1016/j.mayocp.2020.06.028

115. Wooding DJ, Bach H. Treatment of COVID-19 with convalescent plasma: lessons from past coronavirus outbreaks. Clin Microbiol Infect. 2020;26(10):1436-1446. doi:10.1016/j.cmi.2020.08.005

116. US National Library of Medicine. ClinicalTrails.gov. COVID-19 studies from the World Health Organization Database; 2020. Available from: https://clinicaltrials.gov/ct2/who_table. Accessed October 17, 2020.

117. Verma HK, Merchant N, Verma MK, et al. Current updates on the European and WHO registered clinical trials of coronavirus disease 2019 (COVID-19). Biomed J. 2020;S2319-4170(20)30127X. doi:10.1016/j.bj.2020.07.008

118. Mehta N, Mazer-Amirshahi M, Alkindi N, Pourmand A. Pharmacotherapy in COVID-19; A narrative review for emergency providers. Am J Emerg Med. 2020;38(7):1488-1493. doi:10.1016/j.ajem.2020.04.035

119. Montravers P, de Tymowski C, Assadi M, Yung S, Kantor E. Just a little bit more patience .... Anaesth Crit Care Pain Med. 2020;39(3):383-384. doi:10.1016/j.accpm.2020.05.004

120. US Food and Drug Administration. Recommendations for Investigational COVID-19 Convalescent Plasma; 2020. Available from: https://www.fda.gov/vaccines-blood-biologics/investigationalnew-drug-ind-or-device-exemption-ide-process-cber/recommenda tions-investigational-covid-19-convalescent-plasma\#: :text=Because $\% 20$ convalescent $\% 20$ plasma $\% 20$ for $\% 20$ the,plasma $\% 20$ or $\% 20$ pro vide $\% 20$ convalescent $\% 20$ plasma. Accessed October 17, 2020.

121. U.S. Food and Drug Administration. Recommendations for investigational COVID-19 convalescent plasma, s.1.: FDA; 2020. Available from: www.fda.gov/vaccines-blood-biologics/investiga tional-new-drug-ind-or-device-exemption-ide-process-cber/recom mendations-investigational-covid-19-convalescent-plasma. Accessed July 27, 2020.

122. Frazier SK, Higgins J, Bugajski A, Jones AR, Brown MR. Adverse reactions to transfusion of blood products and best practices for prevention. Crit Care Nurs Clin North Am. 2017;29(3):271-290. doi:10.1016/j.cnc.2017.04.002

123. Roback JD, Guarner J. Convalescent Plasma to Treat COVID-19: possibilities and Challenges. JAMA. 2020;323(16):1561. doi:10.1001/jama.2020.4940

124. Seifried E, Schmidt M. Transfusion-transmitted virus infections (TTVIs). Part V: hazards of transfusion. Chapter 51. In: Simon TL, McCullough J, Snyder EL, Solheim BG, Ronald GS, editors. Rossi's Principles of Transfusion Medicine. 5th ed. 9600 Garsington Rd, Cowley, Oxford OX4 2DQ, UK: John Willey and Sons, Ltd; 2016:581-598.

125. Spenser BR. Transfusion transmission of parasites. Part V: hazards of transfusion. Chapter 52. In: Simon TL, McCullough J, Snyder EL, Solheim BG, Ronald GS, editors. Rossi's Principles of Transfusion Medicine. 5th ed. 9600 Garsington Rd, Cowley, Oxford OX4 2DQ, UK: John Willey and Sons, Ltd; 2016:599-607.

126. Benjamin RJ. Bacterial contamination of blood components. Part V: hazards of transfusion. Chapter 53. In: Simon TL, McCullough J, Snyder EL, Solheim BG, Ronald GS, editors. Rossi's Principles of Transfusion Medicine. 5th ed. 9600 Garsington Rd, Cowley, Oxford OX4 2DQ, UK: John Willey and Sons, Ltd; 2016:608619. 
127. Pham TD, Galel SA. Testing for pathogens in donors. Part V: hazards of transfusion. Chapter 53. In: Simon TL, McCullough J, Snyder EL, Solheim BG, Ronald GS, editors. Rossi's Principles of Transfusion Medicine. 5th ed. 9600 Garsington Rd, Cowley, Oxford OX4 2DQ, UK: John Willey and Sons, Ltd; 2016:626631.

128. Maskens C, Downie H, Wendt A, et al. Hospital-based transfusion error tracking from 2005 to 2010: identifying the key errors threatening patient transfusion safety. Transfusion. 2014;54 (1):65-66. doi:10.1111/trf.12240

129. Crookston KP, Koenig SC, Reyes MD. Transfusion reaction identification and management at the bedside. J Infus Nurs. 2015;38(2):104-113. doi:10.1097/NAN.0000000000000097

130. Pérez-Cameo C, Marín-Lahoz J. Serosurveys and convalescent plasma in COVID-19. E Clin Med. 2020;23:100370. doi:10.1016/ j.eclinm.2020.100370

131. Chaurasia R, Zaman S, Das B, Chatterjee K. Screening donated blood for transfusion transmitted infections by serology along with NAT and response rate to notification of reactive results: an indian experience. J Blood Transfus. 2014;2014:412105. doi:10.1155/2014/412105

132. Allain JP, Goodrich R. Pathogen reduction of whole blood: utility and feasibility. Transfus Med. 2017;27(Suppl 5):320-326. doi:10.1111/tme. 12456

133. Eder A, Goldman M, Rossmann S, Waxman D, Bianco C. Selection criteria to protect the blood donor in North America and Europe: past (dogma), present (evidence), and future (hemovigilance). Transfus Med Rev. 2009;23(3):205-220. doi:10.1016/j.tmrv.2009.03.003

134. World Health Organization. How to safely collect blood samples from persons suspected to be infected with highly infectious blood-borne pathogens. (e.g., Ebola), s.l.: WHO; 2014. Available from: euro.who.int/en/health-topics/health-emergen cies/ebola-outbreak-2014/technical-information/laboratory/howto-safely-collect-blood-samples-from-persons-suspected-to-beinfected-with-highly-infectious-blood-borne-pathogens-e.g.ebola. Accessed July 26, 2014.

135. Triulzi DJ, Yazer MH, Waters JH. Patient blood management. Part I: contemporary issues in donation and transfusion. Chapter 2. In: Simon TL, McCullough J, Snyder EL, Solheim BG, Ronald GS, editors. Rossi's Principles of Transfusion Medicine. 5th ed. 9600 Garsington Rd, Cowley, Oxford OX4 2DQ, UK: John Willey and Sons, Ltd; 2016:11-22.

136. Gehrie EA, Chandler J, Snyder EL. Clinical and technical aspects of blood administration. Part I: contemporary issues in donation and transfusion. Chapter 3. In: Simon TL, McCullough J, Snyder EL, Solheim BG, Ronald GS, editors. Rossi's Principles of Transfusion Medicine. 5th ed. 9600 Garsington Rd, Cowley, Oxford OX4 2DQ, UK: John Willey and Sons, Ltd; 2016:23-29.

137. Crookston KP, Pritchard AE, Simon TL. Recruitment and screening of donors and the collection, processing, and testing of blood. Part I: contemporary issues in donation and transfusion. Chapter 4. In: Simon TL, McCullough J, Snyder EL, Solheim BG, Ronald GS, editors. Rossi's Principles of Transfusion Medicine. 5th ed. 9600 Garsington Rd, Cowley, Oxford OX4 2DQ, UK: John Willey and Sons, Ltd; 2016:30-42.

138. Flesland $\varnothing$, Wiersum-Osselton JC. Donor vigilance and hemovigilance. Part I: contemporary issues in donation and transfusion. Chapter 6. In: Simon TL, McCullough J, Snyder EL, Solheim BG, Ronald GS, editors. Rossi's Principles of Transfusion Medicine. 5th ed. 9600 Garsington Rd, Cowley, Oxford OX4 2DQ, UK: John Willey and Sons, Ltd; 2016:58-68.

139. U.S. Food and Drug Administration. Investigational COVID-19 Convalescent Plasma Guidance for Industry, S.1.: FDA; 2020. Available from: www.fda.gov/regulatory-information/search-fdaguidance-documents/investigational-covid-19-convalescentplasma. Accessed 27 July 2020.
140. World Health Organization. Blood donor selection: guidelines on assessing donor suitability for blood donation. World Health Organization; 2012. Available from: https://apps.who.int/iris/han dle/10665/76724. Accessed July 31, 2020.

141. World Health Organization. Ethics of using convalescent whole blood and convalescent plasma during the Ebola epidemic: interim guidance for ethics review committees, researchers, national health authorities, and blood transfusion services. World Health Organization; 2015. Available from: https://apps. who.int/iris/handle/10665/161912. Accessed July 31, 2020.

142. World Health Organization. Use of convalescent whole blood or plasma collected from patients recovered from Ebola virus disease for transfusion, as an empirical treatment during outbreaks: interim guidance for national health authorities and blood transfusion services, Version 1.0 September 2014. World Health Organization; 2014. Available from: https://apps.who. int/iris/handle/10665/135591. Accessed July 31, 2020.

143. Anudeep TC, Jeyaraman M, Shetty DU, et al. Convalescent plasma as a plausible therapeutic option in nCOVID-19: a review. J Clin Trials. 2020;10:409. doi:10.35248/2167-0870.20.10.409

144. Cai X, Ren M, Chen F, Li L, Lei H, Wang X. Blood transfusion during the COVID-19 outbreak. Blood Transfus. 2020;18(2):7982. doi: $10.2450 / 2020.0076-20$

145. Shammi M, Bodrud-Doza M, Towfiqul Islam ARM, Rahman MM. COVID-19 pandemic, socioeconomic crisis, and human stress in resource-limited settings: a case from Bangladesh. Heliyon. 2020;6(5):e04063. doi:10.1016/j.heliyon.2020.e04063

146. Haque M, Islam S, Iqbal S, et al. Availability and price changes of potential medicines and equipment for the prevention and treatment of COVID-19 among pharmacy and drug stores in Bangladesh; findings and implications. Bang J Med Sci. 2020;19(Special Issue COVID-19):S366-SS50. doi:10.3329/bjms.v19i0.48106

147. Hossain MI Covid-19: Bangladesh also exploring plasma therapy as a ray of hope. United News of Bangladesh; 2020. Available from: https:// unb.com.bd/category/Special/covid-19-bangladesh-also-exploringplasma-therapy-as-a-ray-of-hope/52015. Accessed July 1, 2020.

148. Skrip L, Derra K, Kabore M, et al. Clinical management and mortality among COVID-19 cases in sub-Saharan Africa: a retrospective study from Burkina Faso and simulated case analysis. medRxiv. 2020. doi:10.1101/2020.06.04.20119784

149. Pei S, Yuan X, Zhang Z, et al. Convalescent plasma to treat COVID-19: Chinese strategy and experiences. medRxiv. 2020. doi:10.1101/2020.04.07.20056440

150. Haque M High cost of COVID-19 test at Pvt hospitals raises concerns United News of Bangladesh; 2020. Available from: http:/unb.com.bd/category/Special/high-cost-of-covid-19-test-atpvt-hospitals-raises-concern/53389. Accessed July 2, 2020.

151. Ahmed W Treatment denied at hospitals. The Financial Express; 2020. https://thefinancialexpress.com.bd/views/treatment-deniedat-hospitals-1589902122. Accessed July 2, 2020.

152. Tajmim $\mathrm{T}$ Private hospitals unable, unwilling to treat coronavirus patients. The Business Standard; 2020. Available from: https:// tbsnews.net/bangladesh/health/private-hospitals-unable-unwill ing-treat-coronavirus-patients-54169. Accessed July 31, 2020.

153. Center for Policy Dialogue (CPD). Corona pandemic and Bangladesh: health and economic risks and recommendations. Working Paper-133; 2020. Available from: cpd.org.bd/wp-con tent/uploads/2020/04/CPD-Working-Paper-133-CoronaPandemic-and-Bangladesh-Health-and-Economic-Risks-andRecommendations.pdf. Accessed July 2,2020.

154. Lee P, Hsueh P. Emerging threats from zoonotic coronavirusesfrom SARS and MERS to 2019-nCoV. J Microbiol Immunol Infect. 2020;53(3):365-367. doi:10.1016/j.jmii.2020.02.001

155. US Food and Drug Administration. Donate COVID-19 plasma; 2020 Available from: https:/www.fda.gov/emergency-prepared ness-and-response/coronavirus-disease-2019-covid-19/donatecovid-19-plasma. Accessed July 31, 2020. 
156. Mayo Clinic. COVID-19 expanded access program. Plasma donors needed for treatment protocol. 200 First St. SW Rochester, MN 55905, USA; 2020 Available from: https://www. uscovidplasma.org/. Accessed July 31, 2020.

157. Zeng QL, Yu ZJ, Gou JJ, et al. Effect of convalescent plasma therapy on viral shedding and survival in patients with coronavirus disease 2019. J Infect Dis. 2020;222(1):38-43. doi:10.1093/infdis/jiaa228

158. Xia $\mathrm{X}, \mathrm{Li} \mathrm{K}, \mathrm{Wu} \mathrm{L}$, et al. Improved clinical symptoms and mortality on severe/critical COVID-19 patients utilizing convalescent plasma transfusion. Blood. 2020;136(6):755-759. doi:10.1182/blood.2020007079

159. Vieillard V, Astier A, Sauzay C, Paul M. One-month stability study of a biosimilar of infliximab (Remsima $\left.{ }^{\circledR}\right)$ after dilution and storage at $4^{\circ} \mathrm{C}$ and $25^{\circ} \mathrm{C}$. Ann Pharm Fr. 2017;75(1):17-29. doi:10.1016/j.pharma.2016.08.002

160. González-García J, Gutiérrez-Nicolás F, Nazco-Casariego GJ, Viña-Romero MM. Long-term stability of trastuzumab in plasma and whole blood samples stored under different conditions [Estabilidad a largo plazo del trastuzumab en plasma y suero almacenados bajo diferentes condiciones]. Farm Hosp. 2019;43 (2):50-52. doi:10.7399/fh. 11110

161. Stadlbauer D, Baine I, Amanat F, et al. Anti-SARS-CoV2 spike antibodies are stable in convalescent plasma when stored at $4^{\circ}$ Celsius for at least 6 weeks. Transfusion. 2020;60(10):24572459. doi: $10.1111 /$ trf. 16047

162. Tonn T, Corman VM, Johnsen M, et al. Stability and neutralizing capacity of SARS-CoV-2-specific antibodies in convalescent plasma. Lancet Microbe. 2020;1(2):e63. doi:10.1016/S26665247(20)30037-9

163. Vanderwerf JD, Kumar MA. Management of neurologic complications of coagulopathies. Handb Clin Neurol. 2017;141:743764. doi:10.1016/B978-0-444-63599-0.00040-5

164. Iba T, Levy JH, Levi M, Connors JM, Thachil J. Coagulopathy of coronavirus disease 2019. Crit Care Med. 2020;48(9):1358-1364. doi:10.1097/CCM.0000000000004458

165. Iba T, Levy JH, Levi M, Thachil J. Coagulopathy in COVID-19. J Thromb Haemost. 2020;18(9):2103-2109. doi:10.1111/jth.14975

166. Miesbach W, Makris M. COVID-19: coagulopathy, risk of thrombosis, and the rationale for anticoagulation. Clin Appl Thromb Hemost. 2020;26:1076029620938149. doi:10.1177/1076029620938149

167. Aggarwal M, Dass J, Mahapatra M. Hemostatic abnormalities in COVID-19: an update. Indian J Hematol Blood Transfus. 2020;111. doi:10.1007/s12288-020-01328-2

168. Levi M. COVID-19 coagulopathy vs. disseminated intravascular coagulation. Blood Adv. 2020;4(12):2850. doi:10.1182/bloodad vances. 2020002197

169. Terpos E, Ntanasis-Stathopoulos I, Elalamy I, et al. Hematological findings and complications of COVID-19. Am J Hematol. 2020;95(7):834-847. doi:10.1002/ajh.25829

170. Ahmed S, Zimba O, Gasparyan AY. Thrombosis in Coronavirus disease 2019 (COVID-19) through the prism of Virchow's triad. Clin Rheumatol. 2020;39(9):2529-2543. doi:10.1007/s10067-020-05275-1

171. Yu HH, Qin C, Chen M, Wang W, Tian DS. The D-dimer level is associated with the severity of COVID-19. Thromb Res. 2020;195:219-225. doi:10.1016/j.thromres.2020.07.047

172. Becker RC. COVID-19 update: COVID-19-associated coagulopathy. J Thromb Thrombolysis. 2020;50(1):54-67. doi:10.1007/ s11239-020-02134-3

173. Garraud O, Heshmati F, Pozzetto B, et al. Plasma therapy against infectious pathogens, as of yesterday, today and tomorrow. Transfus Clin Biol. 2016;23(1):39-44. doi:10.1016/j. tracli.2015.12.003

174. Luczkowiak J, Arribas JR, Gómez S, et al. Specific neutralizing response in plasma from convalescent patients of Ebola Virus Disease against the West Africa Makona variant of Ebola virus. Virus Res. 2016;213:224-229. doi:10.1016/j.virusres.2015.12.019
175. Luczkowiak J, Lasala F, Mora-Rillo M, Arribas JR, Delgado R. Broad neutralizing activity against ebolaviruses lacking the mucin-like domain in convalescent plasma specimens from patients with ebola virus disease. J Infect Dis. 2018;218 (suppl_5):S574-S581. doi:10.1093/infdis/jiy302

176. Lünemann JD, Nimmerjahn F, Dalakas MC. Intravenous immunoglobulin in neurology - mode of action and clinical efficacy. Nat Rev Neurol. 2015;11(2):80-89. doi:10.1038/nrneur ol.2014.253

177. Bilgin YM, Brand A. Transfusion-related immunomodulation: a second hit in an inflammatory cascade? Vox Sang. 2008;95 (4):261-271. doi:10.1111/j.1423-0410.2008.01100.x

178. Refaai MA, Blumberg N. Transfusion immunomodulation from a clinical perspective: an update. Expert Rev Hematol. 2013;6 (6):653-663. doi:10.1586/17474086.2013.850026

179. Wang Y, Zhang Y, Yu Q, Zhu K. Convalescent plasma coupled with medications for the treatment of a severe covid-19 patient: drugs analysis and pharmaceutical care based on the newly established guidelines for COVID-19 remedy. Front Pharmacol. 2020;11:966. doi:10.3389/fphar.2020.00966

180. Psaltopoulou T, Sergentanis TN, Pappa V, et al. The emerging role of convalescent plasma in the treatment of COVID-19. Hemasphere. 2020;4(3):e409. doi:10.1097/HS9.0000000000 000409

181. Wu Z, McGoogan JM. Characteristics of and important lessons from the coronavirus disease 2019 (COVID-19) outbreak in China: summary of a report of 72314 cases from the Chinese Center for Disease Control and Prevention. JAMA. 2020;323 (13):1239. doi:10.1001/jama.2020.2648

182. Mansourabadi AH, Sadeghalvad M, Mohammadi-Motlagh HR, Rezaei N. The immune system as a target for therapy of SARSCoV-2: a systematic review of the current immunotherapies for COVID-19. Life Sci. 2020;258:118185. doi:10.1016/j.lfs.202 $0.118185 \mathrm{~s}$

183. Zhou G, Zhao Q. Perspectives on therapeutic neutralizing antibodies against the Novel Coronavirus SARS-CoV-2. Int J Biol Sci. 2020;16(10):1718-1723. doi:10.7150/ijbs.451234

184. Sharun K, Tiwari R, Iqbal Yatoo M, et al. Antibody-based immunotherapeutics and use of convalescent plasma to counter COVID-19: advances and prospects. Expert Opin Biol Ther. 2020;20(9):1033-1046. doi:10.1080/ 14712598.2020 .1796963

185. Nurtop E, Villarroel PMS, Pastorino B, et al. Combination of ELISA screening and seroneutralisation tests to expedite Zika virus seroprevalence studies. Virol J. 2018;15(1):192. doi:10.1186/s12985-018-1105-5

186. Yeh KM, Chiueh TS, Siu LK, et al. Experience of using convalescent plasma for severe acute respiratory syndrome among healthcare workers in a Taiwan hospital. J Antimicrob Chemother. 2005;56(5):919-922. doi:10.1093/jac/dki346

187. van Griensven J, Edwards T, Gallian P; Ebola-Tx Consortium. Convalescent plasma for ebola virus disease. $N$ Engl $J$ Med. 2016;374(25):2500. doi:10.1056/NEJMc1602284

188. Accorsi P, Berti P, de Angelis V, De Silvestro G, Mascaretti L, Ostuni A; Italian Society for Transfusion Medicine Immunohaematology (SIMTI) Italian Society for Hemapheresis cell Manipulation (SIdEM). Position paper on the preparation of immune plasma to be used in the treatment of patients with COVID-19. Transfus Apher Sci. 2020;59(4):102817. doi:10.1016/j.transci.2020.102817

189. Anand SP, Finzi A. Understudied factors influencing Fc-Mediated immune responses against viral infections. Vaccines (Basel). 2019;7(3):103. doi:10.3390/vaccines7030103

190. Lewis GK, Pazgier M, Evans DT, et al. Beyond viral neutralization. AIDS Res Hum Retroviruses. 2017;33(8):760-764. doi:10.1089/AID.2016.0299 
191. Salazar E, Perez KK, Ashraf M, et al. Treatment of Coronavirus Disease 2019 (COVID-19) Patients with Convalescent Plasma. Am J Pathol. 2020;190(8):1680-1690. doi:10.1016/j.ajpath.2020.05.014

192. Keller MA, Stiehm ER. Passive immunity in prevention and treatment of infectious diseases. Clin Microbiol Rev. 2000;13 (4):602-614. doi:10.1128/cmr.13.4.602-614.2000

193. Eyler JM. The state of science, microbiology, and vaccines circa 1918. Public Health Rep. 2010;125(Suppl 3):27-36. doi:10.1177/ $00333549101250 \mathrm{~S} 306$

194. Berry CM. Antibody immunoprophylaxis and immunotherapy for influenza virus infection: utilization of monoclonal or polyclonal antibodies? Hum Vaccin Immunother. 2018;14(3):796-799. doi:10.1080/21645515.2017.1363135

195. Annamaria P, Eugenia Q, Paolo S. Anti-SARS-CoV-2 hyperimmune plasma workflow. Transfus Apher Sci. 2020;102850. doi:10.1016/j.transci.2020.102850

196. Kreil TR, Mc Vey JK, Lei LS, et al. Preparation of commercial quantities of a hyperimmune human intravenous immunoglobulin preparation against an emerging infectious disease: the example of pandemic H1N1 influenza. Transfusion. 2012;52(4):803-809. doi:10.1111/j.1537-2995.2011.03347.x

197. Young MK. The indications and safety of polyvalent immunoglobulin for post-exposure prophylaxis of hepatitis A, rubella, and measles. Hum Vaccin Immunother. 2019;15(9):2060-2065. doi:10.1080/21645515.2019.1621148

198. Fleurant-Ceelen A, Tunis M, House A. What is new in the Canadian immunization Guide: November 2016 to November 2018. Can Commun Dis Rep. 2018;44(12):331-335. doi:10.14745/ccdr.v44i12a06

199. Nelson NP, Link-Gelles R, Hofmeister MG, et al. Update: recommendations of the advisory committee on immunization practices for use of Hepatitis A Vaccine for postexposure prophylaxis and for preexposure prophylaxis for international travel. MMWR Morb Mortal Wkly Rep. 2018;67(43):1216-1220. doi:10.15585/mmwr.mm6743a5

200. Khadka S, Yuchi A, Shrestha DB, et al. Repurposing Drugs for COVID-19: an Approach for Treatment in the Pandemic. Altern Ther Health Med. 2020:AT6513.

201. Hachfi W, Ben Lasfar N. COVID-19: main therapeutic options. Tunis Med. 2020;98(4):299-303.

202. Riva L, Yuan S, Yin X, et al. Discovery of SARS-CoV-2 antiviral drugs through large-scale compound repurposing. Nature. 2020;586(7827):113-119. doi:10.1038/s41586-020-2577-1

203. Haque M. The COVID-19 pandemic - a global public health crisis: a brief overview regarding pharmacological interventions. Pesqui Bras Odontopediatria Clín Integr. 2020;20(Suppl 1): e0146. doi:10.1590/pboci.2020.137

204. Estcourt LJ, Roberts DJ. Convalescent plasma for covid-19. BMJ. 2020;370:m3516. doi:10.1136/bmj.m3516

205. Mahase E. Covid-19: US approves emergency use of convalescent plasma despite warnings over lack of evidence. BMJ. 2020;370:m3327. doi:10.1136/bmj.m3327

206. Piechotta V, Chai KL, Valk SJ, et al. Convalescent plasma or hyperimmune immunoglobulin for people with COVID-19: a living systematic review. Cochrane Database Syst Rev. 2020;7 (7):CD013600. doi:10.1002/14651858.CD013600.pub2

207. Eckhardt CM, Cummings MJ, Rajagopalan KN, et al. Evaluating the efficacy and safety of human anti-SARS-CoV-2 convalescent plasma in severely ill adults with COVID-19: a structured summary of a study protocol for a randomized controlled trial. Trials. 2020;21(1):499. doi:10.1186/s13063-020-04422-y

208. Bobek I, Gopcsa L, Réti M, et al. Successful administration of convalescent plasma in critically ill COVID-19 patients in Hungary: the first two cases. [Az első két sikeres, convalescens friss fagyasztott plazmával történő terápia hazai alkalmazása intenzív osztályon kezelt, kritikus állapotú, COVID-19-fertőzésben szenvedő betegekben: (A COVID-19-pandémia orvosszakmai kérdései)]. Orv Hetil. 2020;161 (27):1111-1121. PMID: 32564002. doi:10.1556/650.2020.31901.
209. Zeng H, Wang D, Nie J, et al. The efficacy assessment of convalescent plasma therapy for COVID-19 patients: a multi-center case series. Signal Transduct Target Ther. 2020;5(1):219. doi:10.1038/s41392-020-00329-x

210. Li L, Yang R, Wang J, et al. Feasibility of a pilot program for COVID-19 convalescent plasma collection in Wuhan, China. Transfusion. 2020;60(8):1773-1777. doi:10.1111/trf.15921

211. Kong Y, Cai C, Ling L, et al. Successful treatment of a centenarian with coronavirus disease 2019 (COVID-19) using convalescent plasma. Transfus Apher Sci. 2020;102820. doi:10.1016/j. transci.2020.102820

212. Bloch EM, Goel R, Montemayor C, Cohn C, Tobian AAR. Promoting access to COVID-19 convalescent plasma in lowand middle-income countries. Transfus Apher Sci. 2020;102957. doi:10.1016/j.transci.2020.102957

213. Verhagen LM, de Groot R, Lawrence CA, Taljaard J, Cotton MF, Rabie H. COVID-19 response in low- and middle-income countries: don't overlook the role of mobile phone communication. Int J Infect Dis. 2020;99:334-337. doi:10.1016/j.ijid.2020.07.069

214. Bloch EM, Goel R, Wendel S, et al. Guidance for the procurement of COVID-19 convalescent plasma: differences between high- and low-middle-income countries. Vox Sang. 2020. doi: $10.1111 /$ vox. 12970

215. Weimer A, Tagny CT, Tapko JB, et al. Blood transfusion safety in sub-Saharan Africa: a literature review of changes and challenges in the 21st century. Transfusion. 2019;59(1):412-427. doi: $10.1111 /$ trf. 14949

216. Ware AD, Jacquot C, Tobian AAR, Gehrie EA, Ness PM, Bloch EM. Pathogen reduction and blood transfusion safety in Africa: strengths, limitations, and challenges of implementation in low-resource settings. Vox Sang. 2018;113(1):3-12. doi:10.1111/vox.12620

217. Pruett CR, Vermeulen M, Zacharias P, Ingram C, Tayou Tagny C, Bloch EM. The use of rapid diagnostic tests for transfusion infectious screening in Africa: a literature review. Transfus Med Rev. 2015;29(1):35-44. doi:10.1016/j.tmrv.2014.09.003.25447555

218. Ferreira LMR, Mostajo-Radji MA. Plasma-based COVID-19 treatments in low- and middle-income nations pose a high risk of an HIV epidemic. NPJ Vaccines. 2020;5:58. doi:10.1038/ s41541-020-0209-2

219. Epstein J, Smid WM, Wendel S, Somuah D, Burnouf T. Use of COVID-19 convalescent plasma in low- and middle-income countries: a call for ethical principles and the assurance of quality and safety. Vox Sang. 2020. doi:10.1111/vox.12964

220. Alabdulmonem W, Shariq A, Rasheed Z. COVID-19: a global public health disaster. Int J Health Sci (Qassim). 2020;14(3):7-8.

221. Arshad Ali S, Baloch M, Ahmed N, Arshad Ali A, Iqbal A. The outbreak of Coronavirus Disease 2019 (COVID-19)-An emerging global health threat. J Infect Public Health. 2020;13(4):644-646. doi:10.1016/j.jiph.2020.02.033

222. Contini C, Di Nuzzo M, Barp N, et al. The novel zoonotic COVID-19 pandemic: an expected global health concern. $J$ Infect Dev Ctries. 2020;14(3):254-264. doi:10.3855/jidc.12671

223. Sanders JM, Monogue ML, Jodlowski TZ, Cutrell JB. Pharmacologic Treatments for Coronavirus Disease 2019 (COVID-19): a Review. JAMA. 2020. doi:10.1001/jama.2020.6019

224. Jean SS, Lee PI, Hsueh PR. Treatment options for COVID-19: the reality and challenges. J Microbiol Immunol Infect. 2020;53 (3):436-443. doi:10.1016/j.jmii.2020.03.034

225. Verma HK, Farran B, Bhaskar LVKS. Convalescent plasma transfusion a promising therapy for coronavirus diseases 2019 (COVID-19): current updates. Antibody Ther. 2020;3(2):115125. doi: $10.1093 / \mathrm{abt} / \mathrm{tbaa} 010$

226. Sharma A, Tiwari S, Deb MK, Marty JL. Severe acute respiratory syndrome coronavirus-2 (SARS-CoV-2): a global pandemic and treatment strategies. Int J Antimicrob Agents. 2020;56(2):106054. doi:10.1016/j.ijantimicag.2020.106054 
227. Zhao Q, He Y. Challenges of Convalescent Plasma Therapy on COVID19. J Clin Virol. 2020;127:104358. doi:10.1016/j.jcv.2020.104358

228. Saadah NH, van Hout FMA, Schipperus MR, et al. Comparing transfusion reaction rates for various plasma types: a systematic review and meta-analysis/regression. Transfusion. 2017;57 (9):2104-2114. doi:10.1111/trf.14245

229. Accorsi P, Berti P, de Angelis V, De Silvestro G, Mascaretti L, Ostuni A; Italian Society for Transfusion Medicine and Immunohaematology (SIMTI) and the Italian Society for Haemapheresis and Cell Manipulation (SIdEM). Position paper on the preparation of immune plasma to be used in the treatment of patients with COVID-19. Blood Transfus. 2020;18(3):163-166. doi: $10.2450 / 2020.0124-20$

230. Franchini M. Why should we use convalescent plasma for COVID-19? Eur J Intern Med. 2020;77:150-151. doi:10.1016/j. ejim.2020.05.019

231. World O Meter. COVID-19 Coronavirus Pandemic; 2020. Available from: https://www.worldometers.info/coronavirus/? fbclid=IwAR2U gycDn8i64zB 7 1 xUGm5svanZxQEI U6IEEzgiNRtMnVLtBQtyKqPW_e8. Accessed October 18, 2020.

232. World Health Organization. WHO Director-General's opening remarks at the media briefing on COVID-19-11 March 2020; 2020. Available from: https://www.who.int/dg/speeches/detail/ who-director-general-s-opening-remarks-at-the-media-briefingon-covid-19-11-march-2020., Accessed August 7, 2020.

233. Rust G, Melbourne M, Truman BI, Daniels E, Fry-Johnson Y, Curtin T. Role of the primary care safety net in pandemic influenza. Am $J$ Public Health. 2009;99(Supp12):S316-S323. doi:10.2105/AJPH.2009.161125

234. Kunin M, Engelhard D, Thomas S, Ashworth M, Piterman L. Challenges of the pandemic response in primary care during prevaccination period: a qualitative study. Isr $J$ Health Policy Res. 2015;4:32. doi:10.1186/s13584-015-0028-5

235. Desborough J, Hall Dykgraaf S, Rankin D, Kidd M. The importance of consistent advice during a pandemic: an analysis of Australian advice regarding personal protective equipment in healthcare settings during COVID-19. Aust $J$ Gen Pract. 2020;49(6):369-372. doi:10.31128/AJGP-04-20-5374

236. Desborough J, Hall Dykgraaf S, de Toca L, et al. Australia's national COVID-19 primary care response. Med $J$ Aust. 2020;213(3):104-106.e1. doi:10.5694/mja2.50693

237. Sarti TD, Lazarini WS, Fontenelle LF, Almeida APSC. What is the role of Primary Health Care in the COVID-19 pandemic? Epidemiologia e Serviços De Saúde. 2020;29(2):e2020166. doi:10.5123/s1679-49742020000200024

238. World Health Organization. WHO statement on cases of COVID19 surpassing 100 000; 2020. Available from: https://www.who. int/news-room/detail/07-03-2020-who-statement-on-cases-ofcovid-19-surpassing-100-000. Accessed August 7, 2020.

239. Legido-Quigley H, Asgari N, Teo YY, et al. Are high-performing health systems resilient against the COVID-19 epidemic? Lancet 2020;395(10227):848-850. doi:10.1016/S0140-6736(20)30551-1

240. Chang BB, Chiu TY. Ready for a long fight against the COVID19 outbreak: an innovative model of tiered primary health care in Taiwan. BJGP Open. 2020;4(2):bjgpopen20X101068. doi:10.3399/bjgpopen20X101068

241. Huang WT, Chen YY. The War against the Coronavirus disease (COVID-2019): keys to successfully defending Taiwan. Hu Li Za Zhi. 2020;67(3):75-83. doi:10.6224/JN.202006_67(3).10

242. The Time. What we can Learn from Singapore, Taiwan, and Hong Kong about handling Coronavirus; 2020. Available from: https:// time.com/5802293/coronavirus-covid19-singapore-hong-kong-tai wan/. Accessed August 7, 2020

243. Financial Times. Containing coronavirus: lessons from Asia; 2020. Available from: https://www.ft.com/content/e015e0966532-11ea-a6cd-df28cc3c6a68. Accessed August 7, 2020.
244. Li Yang HSU, Min-Han T. What Singapore can teach the U.S. about responding to Covid-19. STAT. Available from: https:// www.statnews.com/2020/03/23/singapore-teach-united-statesabout-covid-19-response/. Accessed August 7, 2020.

245. Dhama K, Sharun K, Tiwari R, et al. COVID-19, an emerging coronavirus infection: advances and prospects in designing and developing vaccines, immunotherapeutics, and therapeutics. Hum Vaccin Immunother. 2020;16(6):1232-1238. doi:10.1080/ 21645515.2020.1735227

246. Schaefer GO, Tam CC, Savulescu J, Voo TC. COVID-19 vaccine development: time to consider SARS-CoV-2 challenge studies? Vaccine. 2020;38(33):5085-5088. doi:10.1016/j.vaccine.2020.06.007

247. Ministry of Health, Singapore. Confirmed imported case of novel coronavirus infection in Singapore; multi-ministry taskforce ramps up precautionary measures; January 23, 2020. Available from: https://www.moh.gov.sg/news-highlights/details/confirmedimported-case-of-novel-coronavirus-infection-in-singapore-multiministry-taskforce-ramps-up-precautionary-measures. Accessed August 8, 2020.

248. World Health Organization. Coronavirus disease (COVID-19) pandemic; 2020. Available from: https://www.euro.who.int/en/ health-topics/health-emergencies/coronavirus-covid-19/novel-cor onavirus-2019-ncov. Accessed August 8, 2020.

249. Lim WH, Wong WM. COVID-19: notes from the Front Line, Singapore's primary health care perspective. Ann Fam Med. 2020;18(3):259-261. doi:10.1370/afm.2539

250. Taylor Vinters. Singapore - why is the city a global business hub; 2016. Available from: https://www.taylorvinters.com/article/singa pore-city-global-business-hub. Accessed August 8, 2020.

251. Budget Direct Insurance. Singapore Tourism Statistics, 2020. An indepth analysis of the latest tourism statistics for Singapore; 2020. Available from: https://www.budgetdirect.com.sg/travel-insurance/ research/singapore-tourism-statistics. Accessed August 8, 2020.

252. Budget Direct Insurance. Medical Tourism Singapore, 2020. An in-depth analysis of Medical Tourism in Singapore. Available from: https://www.budgetdirect.com.sg/travel-insurance/research/ medical-tourism-singapore. Accessed August 8, 2020.

253. Lin RJ, Lee TH, Lye DC. From SARS to COVID-19: the Singapore journey. Med J Aust. 2020;212(11):497-502.e1. doi:10.5694/mja2.50623

254. Dan YY, Tambyah PA, Sim J, et al. Cost-effectiveness analysis of hospital infection control response to an epidemic respiratory virus threat. Emerg Infect Dis. 2009;15(12):1909-1916. doi:10.3201/eid1512.090902

255. Koh Y, Hegney D, Drury V. Nurses' perceptions of risk from emerging respiratory infectious diseases: a Singapore study. Int $J$ Nurs Pract. 2012;18(2):195-204. doi:10.1111/j.1440172X.2012.02018.x

256. Yang Y, Shang W, Rao X. Facing the COVID-19 outbreak: what should we know and what could we do. J Med Virol. 2020;92 (6):536-537. doi:10.1002/jmv.25720

257. Kunin M, Engelhard D, Piterman L, Thomas S. Response of general practitioners to infectious disease public health crises: an integrative systematic review of the literature. Disaster Med Public Health Prep. 2013;7(5):522-533. doi:10.1017/dmp.2013.82

258. Kumar P. How to strengthen primary health care. J Fam Med Prim Care. 2016;5(3):543-546. doi:10.4103/2249-4863.197263

259. Haque M, Islam T, Rahman NAA, McKimm J, Abdullah A, Dhingra S. Strengthening primary health-care services to help prevent and control long-term (chronic) non-communicable diseases in low- and middle-income countries. Risk Manag Healthc Policy. 2020;13:409-426. doi:10.2147/RMHP.S239074

260. Jiang F, Deng L, Zhang L, Cai Y, Cheung CW, Xia Z. Review of the clinical characteristics of Coronavirus disease 2019 (COVID19). J Gen Intern Med. 2020;35(5):1545-1549. doi:10.1007/ s11606-020-05762-w 
261. Huang C, Wang Y, Li X, et al. Clinical features of patients infected with 2019 novel coronavirus in Wuhan, China. Lancet. 2020;395(10223):497-506. doi:10.1016/S0140-6736(20)30183-5

262. Khoo HS, Lim YW, Vrijhoef HJ. Primary healthcare system and practice characteristics in Singapore. Asia Pac Fam Med. 2014;13 (1):8. doi:10.1186/s12930-014-0008-x

263. Health Information Division, Ministry of Health, Singapore Primary Care Survey 2014. Available from: https://www.moh. gov.sg/docs/libraries. Accessed August 8, 2020.

264. Tan Z, Khoo DWS, Zeng LA, et al. Protecting health care workers in the front line: innovation in COVID-19 pandemic. $J$ Glob Health. 2020;10(1):010357. doi:10.7189/jogh.10.010357

265. Chang CM, Tan TW, Ho TC, Chen CC, Su TH, Lin CY. COVID19: Taiwan's epidemiological characteristics and public and hospital responses. Peer J. 2020;8:e9360. doi:10.7717/peerj.9360

266. Jan CF, Chiu TY, Chen CY, Guo FR, Lee MC. A 10-year review of health care reform on Family Practice Integrated Care ProjectTaiwan experience. Fam Pract. 2018;35(4):352-357. doi:10.1093/fampra/cmx111
267. Lin C, Braund WE, Auerbach J, et al. Policy Decisions and Use of Information Technology to Fight COVID-19, Taiwan. Emerg Infect Dis. 2020;26(7):1506-1512. doi:10.3201/eid2607.200574

268. Pulia MS, O’Brien TP, Hou PC, Schuman A, Sambursky R. Multitiered screening and diagnosis strategy for COVID-19: a model for sustainable testing capacity in response to pandemic. Ann Med. 2020;52(5):207-214. doi:10.1080/07853890.2020.1763449

269. Agarwal A, Mukherjee A, Kumar G, Chatterjee P, Bhatnagar T, Malhotra P; PLACID Trial Collaborators. Convalescent plasma in the management of moderate covid-19 in adults in India: open-label phase II multicentre randomized controlled trial (PLACID Trial). BMJ. 2020;371:m3939. doi:10.1136/bmj.m3939
Risk Management and Healthcare Policy

\section{Publish your work in this journal}

Risk Management and Healthcare Policy is an international, peerreviewed, open access journal focusing on all aspects of public health, policy, and preventative measures to promote good health and improve morbidity and mortality in the population. The journal welcomes submitted papers covering original research, basic science, clinical \& epidemiological studies, reviews and evaluations,
Dovepress

guidelines, expert opinion and commentary, case reports and extended reports. The manuscript management system is completely online and includes a very quick and fair peer-review system, which is all easy to use. Visit http://www.dovepress.com/testimonials.php to read real quotes from published authors. 